\title{
Executive equity incentives and opportunistic manager behavior: new evidence from a quasi-natural experiment
}

\author{
Martin Nienhaus ${ }^{1}$
}

Accepted: 25 July 2021 / Published online: 2 December 2021

(C) The Author(s) 2021

\begin{abstract}
This study provides plausible causal evidence on the effect of executive equity incentives on opportunistic manager behavior. I exploit a unique setting created by the introduction of Financial Accounting Standard (FAS) 123R in 2005, which led to an exogenous increase in the cost of option pay, causing a substantial decline in option pay for some firms while leaving others largely unaffected. Using difference-indifferences analyses with a treatment group of firms that show a decline in option pay and two control groups, I find that the likelihood of a treatment firm meeting or beating analyst forecasts decreases by $14-20 \%$. The results show that the relatively high levels of meet-or-beat before FAS $123 \mathrm{R}$ were largely driven by real activities manipulation such as abnormal asset sales and sales manipulation to beat analysts' benchmarks, while accrual manipulation and analyst management were less relevant. Together, the results suggest that equity incentives encourage opportunistic actions to meet or beat earnings expectations, and a decline in option pay results in a decline in earnings management to meet earnings expectations.
\end{abstract}

Keywords Executive compensation · Equity incentives · Beating analysts' forecasts · FAS 123R · Quasi-natural experiment

JEL classification M41 $\cdot$ G38

\section{Introduction}

The main rationale behind executive equity incentives is to align managers' interests with those of shareholders. For public firms, stock options are the most widely used

Martin Nienhaus

nienhaus@wiwi.uni-frankfurt.de

1 Goethe-University Frankfurt, Theodor-W.-Adorno-Platz 4, 60323 Frankfurt am Main, Germany 
instrument among different forms of equity-based compensation because they serve two important purposes. First, option pay makes manager wealth sensitive to changes in stock prices (delta). Second, the convexity in the option's payoff structure (vega) incentivizes risk-averse, undiversified managers to adopt risky, positive net present value (NPV) projects. Hence, in an agency framework, stock options should motivate managers to make decisions that maximize shareholder wealth (Jensen and Meckling 1976; Haugen and Senbet 1981). While the use of option pay for management compensation dramatically increased during the 1990s (Murphy 1999), it also became controversial. Critics feared that managers would focus on short-term stock prices. Regulators and investors voiced concerns that option pay encourages opportunistic management behavior and contributes to corporate scandals (Levitt 1998; Knowledge at Wharton 2003). For example, in 2002, the chairman of the Federal Reserve Board, Greenspan (2002), referred to stock option pay for managers as an "infectious greed" that "perversely created incentives to artificially inflate reported earnings in order to keep stock prices high and rising."

To analyze whether option pay indeed causes opportunistic management behavior, I study how option pay affects the ability of managers to meet analysts' expectations. ${ }^{1}$ Many studies suggest that managers act opportunistically to beat analysts' forecasts. ${ }^{2}$ The opportunistic actions include (1) "within GAAP" accrual management (e.g., Abarbanell and Lehavy 2003; Burgstahler and Eames 2006; McVay et al. 2006), (2) real activities manipulation (e.g., Roychowdhury 2006; Gunny 2010), (3) analyst expectations management (e.g., Kasznik and Lev 1995; Matsumoto 2002; Doyle et al. 2013), and (4) "outside of GAAP" manipulations (e.g., Chu et al. 2019). Instead of focusing on any single actions, I use "meet or beat" as a summary measure to capture a wide variety of opportunistic accounting actions and real actions. Another desirable feature of using meeting or just beating analysts' forecasts to capture opportunistic manager behavior is that it has more direct market consequences than other measures. For example, Bartov et al. (2002) and Kasznik and McNichols (2002) show that the market rewards firms that beat analysts' forecasts, while Skinner and Sloan (2002) and Lopez and Rees (2002) provide evidence of negative market consequences when analysts' forecasts are missed. Hence, a direct link exists between beating analysts' forecasts and stock prices, which ultimately affects option pay. Ken Brown (2002) supports this notion and notes, in his Wall Street Journal column, that "the reasons that executives became so obsessed with hitting their numbers are clear. ... [It] goes a long way toward keeping the executives' stock options in the money."

From a theoretical perspective, however, whether option pay encourages opportunistic management behavior is unclear. On one hand, option pay makes CEO wealth sensitive to stock prices. Thus, option pay may create incentives to artificially inflate prices through opportunistic actions. On the other hand, opportunistic actions likely increase risk, and risk-averse managers may avoid taking risky actions because the

\footnotetext{
${ }^{1}$ Throughout the study, I use the expressions "beating analysts' forecasts," "meeting analysts' expectations," and "meet or beat" to refer to narrowly meeting or beating analysts' forecasts (i.e., earnings surprise per share within $[\$ 0 ; \$ 0.01$ or $\$ 0.02]$ ).

${ }^{2}$ I acknowledge that other non-equity incentives-driven motivations may exist to meet or beat analysts' forecasts. For example, Allen et al. (2017) show that individuals engage in reference-dependent target beating even without monetary incentives. If this was the primary reason for firms to meet or beat earnings expectations, I should not observe a change in meet or beat when equity incentives change.
} 
delta of stock options magnifies the effect of stock price volatility on the volatility of manager wealth (Armstrong et al. 2013). ${ }^{3}$ Moreover, managers weigh the benefits of inflated earnings against the costs of earnings management. Given that earnings management is costly and often comes at the expense of long-term value creation (e.g., Jensen 2005), managers manipulate earnings only if the marginal benefits exceed the costs. The vast extant empirical literature on this topic has also reported inconclusive findings. ${ }^{4}$

This study helps to resolve this open question by using a quasi-natural experiment to provide plausible causal evidence. Generally, establishing causality between executive compensation and opportunistic management behavior is difficult because both are endogenously determined. For example, firms with a risk-averse board of directors may choose to grant fewer options. Simultaneously, these boards may scrutinize and monitor managers more intensively, thereby curbing the management's ability to act opportunistically. Alternatively, managers who are less aggressive in their use of earnings management may choose to work for firms that grant fewer options. Hence, any empirical relation between option pay and opportunistic management behavior may be spurious. Edmans and Gabaix (2015) also note that, because of a lack of valid instrumental variables, prior research has not satisfactorily identified the general effects of executive compensation. I tackle these endogeneity concerns in the context of option pay and opportunistic management behavior by exploiting plausible exogenous variation in option pay created by the introduction of Financial Accounting Standard (FAS) $123 \mathrm{R}$ in 2004.

The introduction of FAS 123R prohibited the use of the intrinsic value method and mandated the fair value method. Under the fair value method, the fair value of the options is recognized as an expense. In contrast, the intrinsic value method avoided expensing options when the exercise price was less than or equal to the grant date stock price. Prior to FAS 123R, firms could choose either method. Unsurprisingly, few firms opted for the fair value method before FAS 123R, even though the previous standard, FAS 123, encouraged them to do so.

The change in rules led to a substantial decline in option pay. I identify two groups that were likely not affected by FAS 123R: (1) firms that did not grant their CEOs any options from 2002 to 2004, and (2) firms that voluntarily opted for the fair value method before it became mandatory. Both groups serve as control firms in a differencein-differences research design. First, I confirm that FAS 123R led to a substantial change in equity incentives for the treatment firms. As expected, the ratio of option compensation to total compensation for treatment firms declined on average from $47 \%$ in the pre-FAS $123 \mathrm{R}$ period to $29 \%$ in the post-FAS $123 \mathrm{R}$ period. The first control

\footnotetext{
${ }^{3}$ Consider a simple example of a CEO who holds a stock option that is deep in the money. Compared with a stock option that is at the money, the option that is deep in the money will have a relatively low vega and a relatively high delta. Thus, a deep-in-the-money stock option will, ceteris paribus, disincentivize a risk-averse CEO from taking risky actions (such as earnings management or misreporting) because the CEO will be incentivized to preserve the intrinsic value of his option, which manifests as a relatively high delta. Hence, the delta in the option's payoff structure may disincentivize opportunistic management behavior.

${ }^{4}$ See, for example, Ke (2001), Gao and Shrieves (2002), Baker et al. (2003), Johnson et al. (2003), Bartov and Mohanram (2004), Cheng and Warfield (2005), Bergstresser and Philippon (2006), Burns and Kedia (2006), Denis et al. (2006), Erickson et al. (2006), O’Conner et al. (2006), Efendi et al. (2007), Cohen et al. (2008), McAnally et al. (2008), Peng and Röell (2008), Armstrong et al. (2010), Jiang et al. (2010), Feng et al. (2011), Armstrong et al. (2013), Jayaraman and Milbourn (2015), and Quinn (2018).
} 
group, by contrast, shows a 13-percentage-point increase in the option pay ratio. The second control group shows a nonsignificant decline in option compensation of 4 percentage points. Similarly, treatment firms show a substantial decline in payperformance sensitivity (delta) and sensitivity to stock price volatility (vega) for compensation packages granted after FAS 123R. Hence, FAS 123R caused a substantial decline in option pay and related incentives for the treatment group.

In my main test, I compare changes in the behavior of beating analysts' forecasts of the treatment and control firms in the pre- and post-FAS 123R periods. My final sample consists of 3,256 firm-year observations of non-financial firms for three years in the pre-FAS 123R period (2002-2004) and the post-FAS 123R period (2005-2007) each. I find a highly significant decline in beating analysts' forecasts for the treatment group. This effect is also economically meaningful: on average, the likelihood of beating analysts' forecasts decreases by $14-20 \%$ for the treatment group compared to the control group.

I conduct a battery of tests to corroborate the main results. First, I ensure that the treatment and control groups are largely similar in the pre-FAS 123R period, and I find similar results using propensity score matching (PSM). Second, while FAS 123R led to a substantial change in option pay for the treatment group, I show that treatment firms did not experience any changes in other fundamental firm characteristics compared with control firms. Such changes in other firm characteristics could also influence managers' incentives for earnings management. Hence, concurrent changes in other observable firm characteristics are unlikely to drive the results. Third, consistent with my expectations, I show that the effect of the decline in beating analysts' forecasts is stronger for firms that are affected to a greater extent by FAS 123R (as measured by their 2002 amount of implied option expenses). Fourth, I conduct several tests that support the parallel trends assumption. Specifically, a graphical inspection of the fraction of firms meeting or beating analyst forecasts over time shows that the treatment and control groups display virtually similar trends before FAS 123R. Moreover, a falsification test shows that the effect does not hold around a placebo event. Finally, I exploit the fact that I have two control groups that differ from each other since firms in one group did not grant any options before FAS 123R and firms in the other group chose to expense their options. Because of these differences, any potential biases arising from pre-treatment differences in the control groups are likely different from each other. As I find similar results when I replicate my analyses using each control group separately, my main results are unlikely to be contaminated by either bias. I also conduct several other tests, the results of which all support my main results and suggest a direct link between option pay and beating analysts' forecasts.

To corroborate that the decrease in the meet-or-beat phenomenon is consistent with an earnings management explanation, I show that the decline in beating analysts' targets is accompanied by a decline in real activities manipulation, such as abnormal asset sales and discretionary sales manipulation. However, consistent with Dechow et al. (2003), I find no evidence that accrual manipulation is behind target beating in my sample. Finally, I complement the archival results with an exploratory field study via semi-structured interviews with CEOs of firms that are part of my sample. In these interviews, CEOs acknowledge the opportunistic incentives of option pay and detail the channels through which they meet or beat earnings targets. In particular, CEOs refer to discretionary sales manipulation, which is consistent with the archival results. These 
additional tests support my main finding of a causal link between executive equity incentives and earnings management. Overall, the results imply that equity incentives encourage opportunistic actions to meet or beat earnings expectations, and a decline in option pay causes a decline in earnings management to meet earnings expectations.

This study contributes to the inconclusive literature on executive compensation and opportunistic management behavior. While prior research has largely focused on associations, I exploit an exogenous change to stock option costs, caused by FAS 123R, that allows me to provide a plausible causal link between option pay and beating analysts' forecasts. This setting is particularly important for a research question concerning executive compensation and management behavior, given their endogenous nature. Because of the mixed results in previous studies, my finding of a positive effect of option pay on beating analysts' targets helps to answer this previously unresolved research question.

Moreover, I shed new light on the channels used to meet or beat earnings targets and thereby provide additional insights into the literature on discontinuities in earnings distributions, which was spawned by Hayn (1995) and Burgstahler and Dichev (1997). Prior research has offered mixed evidence. For example, Dechow et al. (2003) find no evidence of accrual manipulation, while Ayers et al. (2006) find that forward-looking accruals are higher for small profit firms. Phillips et al. (2003), however, only find evidence of manipulation for a specific accrual (i.e., deferred tax expenses). Roychowdhury (2006) shows that firms use real activities manipulation to avoid reporting losses, while the result for beating analysts' forecasts is less robust. Other studies offer explanations unrelated to earnings management (e.g., Durtschi and Easton 2005; Durtschi and Easton 2009; Beaver et al. 2007). My results, based on a uniquely strong change in the meet-or-beat phenomenon, corroborate the results of Dechow et al. (2003) and Roychowdhury (2006) for analysts' earnings targets and thus add to our understanding of earnings discontinuities.

\section{Executive stock options and FAS 123R}

In the 1990s, the use of stock options for executive compensation skyrocketed (Murphy 1999). Part of the reason for this increase was a 1993 tax law, signed by Bill Clinton, that was intended to curb excessive CEO pay. The law introduced section $162(\mathrm{~m})$ of the Internal Revenue Code, which stated that companies may deduct only the first $\$ 1$ million of compensation for their top five executives. This $\$ 1$ million cap, however, applied only to non-performance-based pay. Hence, stock options and other performance-based incentives were deductible even if they were in excess of $\$ 1$ million. As a result, stock option pay increased substantially.

The accounting rules at that time also provided firms with incentives for option pay. From 1972 to 1995, Accounting Principles Board (APB) Opinion No. 25, Accounting for Stock Issued to Employees, concerned accounting for stock options. ABP No. 25 required use of the intrinsic value method, under which the expense for granting stock options was the difference between the exercise price and the grant price. Consequently, firms avoided recognizing an expense when options were granted at the money (i.e., the exercise price equals the grant price). In 1995, the Financial Accounting Standards Board (FASB) revised APB No. 25 and issued FAS 123. FAS 123 encouraged the use of the fair value method, which requires firms to recognize an expense based on the fair 
value of the option by using option valuation techniques such as the Black-Scholes model. Although the FASB unanimously held the view that the fair value method should be used, the final version of FAS 123 allowed both the intrinsic value method and the fair value method because of an extensive political controversy. ${ }^{5}$ The FASB noted that "the debate on accounting for stock-based compensation unfortunately became so divisive that it threatened the Board's future working relationship with some of its constituents ... [and] threatened the future of accounting standards setting in the private sector" (Basis for Conclusion FAS 123, FASB 1995, 60). Nevertheless, when choosing the intrinsic value method, firms had to disclose the fair value of options and its impact on their earnings in the footnotes.

Unsurprisingly, a negligible number of firms followed the FASB's suggestion in FAS 123 to voluntarily opt to use the fair value method. The accounting landscape, however, changed in the early 2000s after the prominent corporate scandals and financial reporting failures of Enron and WorldCom. Driven by a new demand for transparency and encouraged by advocates such as Warren Buffett and Alan Greenspan, firms such as Coca-Cola, Boeing, and Winn-Dixie Stores started to expense their options by using the fair value method in 2002. Warren Buffet, Coca-Cola's largest shareholder and a board member at that time, commented that he would feel "far more comfortable" if other firms would follow Coca-Cola's lead (Wall Street Journal 2002). In fact, this decision placed pressure on other firms. Within the next two years, more of them started to voluntarily expense options.

Meanwhile, the concurrent political discussions also led the FASB to reconsider accounting for options. In 2004, the FASB issued FAS 123R, which eliminated the favorable accounting treatment of the intrinsic value method, effective for fiscal years beginning on or after June 15, 2005. Henceforth, all firms were required to recognize an expense over the vesting period based on the fair value of options. When adopting FAS 123R, firms could choose either the modified retrospective method or the modified prospective method. The modified retrospective method required firms to restate all prior periods since December 15, 1994, as if the fair value method had always been applied. However, very few companies chose it (McConnell et al. 2006). Most firms opted for the prospective method, which required them to expense only the fair value of unvested options and new option grants. Most other equity-based forms of compensation, such as restricted stock or performance-based equity awards, were largely unaffected by FAS 123R. The tax treatment of stock options also did not change after FAS $123 \mathrm{R}$. Hence, FAS 123R resulted in a unique and exogenous change in the incentives for option pay without affecting other compensation-related matters.

\section{Related research and theory}

\subsection{Option pay and opportunistic management behavior}

The main intuition behind option pay is to align the interests of outside shareholders with those of managers (Jensen and Meckling 1976; Haugen and Senbet 1981). The

\footnotetext{
${ }^{5}$ For example, more than 1,700 comment letters were submitted regarding the exposure draft of FAS 123 in 1993. Most opposed the fair value method. For more details on the controversy surrounding FAS 123 , refer to Dechow et al. (1996a).
} 
pay-performance sensitivity (delta) of option pay makes managers' wealth sensitive to stock prices and thus creates incentives for managers to exert sufficient effort. While equity ownership may cause risk-averse, undiversified managers to reject risky, positive-NPV projects, the convexity of the payoff structure of stock options (vega) incentivizes managers to be less risk-averse (e.g., Smith and Stulz 1985). Hence, option pay is considered an important mechanism to increase shareholder value.

There is, however, a large body of literature (discussed below) on, and a general concern (see examples in the introduction) about, the possibility that option pay creates opportunistic management behavior. Cheng and Warfield (2005) offer a classic view of this concern and identify two conditions under which option pay can increase opportunistic management behavior. First, investors must rely on current earnings as they build their expectations about future earnings. In this case, earnings management can influence stock prices. Stein (1989) supports this notion by arguing that investors use current earnings to forecast firm value. The link between earnings and stock prices has also been empirically well established since Ball and Brown (1968). Second, managers must be able to benefit from increased stock prices. Managers are usually granted a certain package of options on a regular basis. These options usually do not vest until a few years later (Cheng and Warfield 2005). The regularity of option granting, together with schedules that partially vest options over usually two to four years (e.g., Hall and Murphy 2002), leads to exercisable options each year. Hence, managers can directly benefit by increasing stock prices through earnings management. ${ }^{6}$ Following Cheng and Warfield (2005), incentives for earnings management do not exist only when the market is naïvely fixating on earnings. Stein (1989) shows that even if the market is not fooled by earnings management, investors rationally expect a certain degree of earnings management and consider this factor when using current earnings to forecast firm value. Consequently, the Nash equilibrium in this situation involves opportunistic earnings management behavior because such behavior is expected by the market. Hence, this classic view predicts that option pay encourages opportunistic management behavior.

Armstrong et al. (2013) offer a slightly different and more nuanced view of the theoretical impact of option pay on opportunistic management behavior. They conjecture that the delta and vega of option pay may provide countervailing incentives. When opportunistic management behavior is considered a special case of a risky project that increases equity value and equity risk, the "reward effect" of delta predicts project adoption, because managers benefit from the increase in equity value. By contrast, the "risk effect" predicts project rejection for risk-averse managers, because delta magnifies the effect of stock price volatility on the volatility of manager wealth (e.g., Lambert et al. 1991; Ross 2004; Armstrong and Vashishtha 2012). The downside risk of

\footnotetext{
${ }^{6}$ At exercise dates, managers have straightforward incentives to increase earnings to meet targets. Because options are usually granted at the money, managers could also be encouraged to decrease earnings to miss targets when options are granted. The incentives for upward earnings management are likely stronger for several reasons. Managers are reluctant to harm the firm's reputation or permanently decrease its market value. Moreover, regularly missing targets could get managers fired (Fama 1980) or decrease their other compensation (e.g., bonuses, unexercised stock options or stock held). Similarly, intentional downward earnings management may violate debt covenants and affect firm growth (McAnally et al. 2008). Alternatively, managers may not use earnings to maximize their pay from options; however, they can retroactively time the grant dates (i.e., backdating) (Lie 2005; Heron and Lie 2007; Ertimur et al. 2012) or influence boards to opportunistically time option grants (Yermack 1997).
} 
opportunistic management actions can be particularly severe. For example, Feroz et al. (1991) and Dechow et al. (1996b) find negative returns of -9 to $-10 \%$ on the day Accounting and Auditing Enforcement Releases (AAERs) are announced. Palmrose et al. (2004) document negative abnormal two-day returns of $-20 \%$ for restatements related to fraud, and Karpoff et al. (2008) find that firms experience an average decline in market value of $-38 \%$ after SEC enforcement actions. These extreme negative returns may discourage risk-averse managers from engaging in opportunistic behavior. Hence, under the assumption that opportunistic management behavior increases stock prices but also increases risk, the incentive effects of delta are countervailing. In contrast, vega provides unambiguous incentives to adopt risky projects because, ceteris paribus, managers' portfolio wealth increases with firm risk. Ultimately, the more nuanced view does not allow a clear prediction of the effect of option pay on the probability of managers acting opportunistically. ${ }^{7}$

This mixed expectation is also reflected in the mixed results of prior research. Several studies show a positive association between equity incentives and the use of discretionary accruals (Gao and Shrieves 2002; Baker et al. 2003; Bartov and Mohanram 2004; Bergstresser and Philippon 2006; Cohen et al. 2008; Jiang et al. 2010). Evidence on fraud and accounting misstatements, however, is mixed. Burns and Kedia (2006) and Efendi et al. (2007) provide evidence of a positive relation between a CEO's option portfolio and the likelihood of misstatements, and Peng and Röell (2008) find that option pay is positively related to private securities litigation. Similarly, Denis et al. (2006) show a positive relation between executive stock option incentives and fraud allegations.

By contrast, Johnson et al. (2003) find no evidence for an association of vested and unvested stocks with fraudulent financial statements, and Erickson et al. (2006) find no consistent evidence of a link between executive equity incentives and accounting fraud. Likewise, O'Connor et al. (2006) find that large stock option grants are sometimes associated with a lower probability of fraudulent reporting and sometimes associated with a higher probability, depending on other corporate governance factors. Relatedly, Jayaraman and Milbourn (2015) only find a positive relation of CEO equity incentives with misreporting when auditor expertise is low. Feng et al. (2011) document a positive association of CEO equity incentives with material accounting manipulations but find that $\mathrm{CFO}$ equity incentives are unrelated to manipulations. Armstrong et al. (2010) even find a modest negative association between CEO equity incentives and accounting irregularities after matching CEOs based on the observable characteristics of their contracting environments. Similarly, Armstrong et al. (2013) find a negative association between equity incentives and misreporting. This relation, however, is solely driven by the vega-not the delta - of the equity incentives' payoff structure.

\footnotetext{
${ }^{7}$ Note, however, that this assessment is based on a ceteris paribus discussion. In my empirical setting, it is likely that a decrease in option pay will be accompanied by changes in other equity instruments, such as increases in (restricted) stock. In this case, the effect ultimately depends on the overall changes in delta and vega (which I test below).
} 
With regard to beating analysts' forecasts, the results are only partially mixed. Ke (2001), Baumann and Shaw (2006), and Cheng and Warfield (2005) find a positive association between stock-based compensation and beating earnings targets. However, Quinn (2018) finds that after the adoption of stock ownership plans that require CEOs to increase stock ownership, firms exhibit a decreased propensity to meet or just beat analysts' forecasts. Bauman et al. (2005) find a positive association between optionbased compensation and the likelihood that a firm uses analyst guidance to meet or beat forecasts. However, they find no association between option-based compensation and firms beating analyst forecasts by using abnormal accruals. McAnally et al. (2008) find that option grants are related to missed earnings targets.

Overall, the discussion of prior research allows several important observations. First, evidence regarding the relation between executive equity incentives and opportunistic management behavior is mixed. Second, the vast majority of prior research is based on regression designs that are susceptible to several endogeneity concerns (as elaborated below). Armstrong et al. (2013) conjecture that the mixed findings in prior research could result from differences in research designs. Studies that document a positive relation between equity incentives and misreporting tend to use regression designs (e.g., Bergstresser and Philippon 2006; Burns and Kedia 2006), while studies that find no or a negative relation are based on matched-pair designs (e.g., Erickson et al. 2006; Efendi et al. 2007; Armstrong et al. 2010). While matching is an important step toward addressing the selection issue, it will not work unless the factors used for it have been carefully assessed. Erickson et al. (2006) and Efendi et al. (2007) use a simple within-industry-year matching based on similar size. This approach is susceptible to a variety of alternative explanations related to corporate governance factors or CEO characteristics that may differ for similarly sized firms. Armstrong et al. (Armstrong et al. 2010; Armstrong et al. 2013) ${ }^{8}$ and Quinn (2018) avoid this concern by matching on the probability that an executive will receive a certain level or form of equity compensation based on the contracting environment of a firm. So far, these three studies have addressed the inherent endogeneity concerns most effectively. ${ }^{9}$

This study, however, differs in several important ways from Armstrong et al. (Armstrong et al. 2010, Armstrong et al. 2013) and Quinn (2018). Armstrong et al. (2010, 2013) largely focus on "outside of GAAP" manipulation captured by restatements and the SEC's Accounting and Auditing Enforcement Releases (AAERs), which reflect very severe transgression. Quinn (2018) uses the initiation of stock ownership plans, which have a different effect on CEOs' incentives because they affect delta but not vega. The most important difference, however, is that Armstrong et al. (2010, 2013) and Quinn (2018) lack exogenous variation, while I exploit plausible exogenous variation in option pay created by the introduction of FAS 123R in 2004. In this regard, using a quasi-natural experiment to overcome endogeneity issues helps to resolve the question of whether option pay leads to beating analysts' forecasts (Graham et al. 2005). Because theoretical expectations and evidence in prior research are mixed, I ultimately regard the effect of option pay on beating analysts' forecasts as an empirical question.

\footnotetext{
$\overline{8}$ Jayaraman and Milbourn (2015) replicate the results in Armstrong et al. (2010) and confirm their findings.

${ }^{9}$ Note that a concurrent study by Ladika and Sautner (2020) is also well identified by exploiting different fiscal-year ends around FAS $123 \mathrm{R}$ as an instrument for short-term equity incentive horizons. They find that managers cut investments when their incentives become more short-term. I, however, focus on earnings management.
} 


\section{Empirical methodology}

\subsection{Identification strategy}

Establishing causality between option pay and opportunistic management behavior is difficult. In their literature review, Frydman and Jenter $(2010,96)$ conclude that "measuring [compensation arrangements'] causal effects on behavior and firm value is extremely difficult and remains one of the most important challenges for research on executive pay." In equilibrium, option pay and opportunistic management behavior are jointly determined based on a variety of factors, some of which are unobservable. For example, it is difficult to observe and measure managers' risk aversion and the strength of firms' corporate governance. However, omitting these factors or using poor proxies for them can lead to biased estimates. The matching process in the labor market can also lead to selection bias. For example, a manager may select a firm with a compensation plan that suits her risk aversion. Concurrently, a manager's risk aversion can affect the likelihood of her behaving opportunistically. Hence, most archival studies that attempt to analyze the link between option pay and opportunistic management behavior suffer from endogeneity concerns. To address these concerns, I exploit a quasi-natural experiment created by FAS 123R, whose introduction in 2004 created an exogenous change in the accounting costs of option pay while leaving the underlying economic benefits unaffected (Hayes et al. 2012). Moreover, the first-order effect of FAS $123 \mathrm{R}$ on the costs of option pay is arguably exogenous to beating analysts' forecasts, which is important for establishing causality.

The FASB had expected that firms would reassess whether the expected benefits of a stock option plan justify the costs after adopting FAS 123R. If the motivational benefits of a stock option program to increase revenues (or decrease expenses) were offset by the reported compensation costs, firms would probably eliminate or restrict stock option programs. In fact, the use of stock options for management compensation declined substantially owing to FAS 123R (e.g., Carter et al. 2009; Brown and Lee 2011; Hayes et al. 2012). This substantial effect of FAS 123R on option pay is interesting because users of financial statements could have reconciled the fair value costs of stock option compensation from the footnotes before FAS 123R. Nevertheless, plenty of evidence shows that investors incorporate less information from footnote disclosures than from recognized amounts (e.g., Barth et al. 2003; Ahmed et al. 2006). ${ }^{10}$

I identify two groups that were likely not affected by FAS $123 \mathrm{R}$. The first group comprises firms that did not grant their CEOs any options from 2002 to 2004, which I identify based on the compensation information in ExecuComp. The second group comprises firms that voluntarily opted for the fair value method in or before 2003. Similar to Bakke et al. (2016), I obtain a list of firms that voluntarily expensed stock options prior to FAS 123R from Bear Stearns Equity Research dated December 16, 2004 (McConnell et al. 2004). Both groups serve as control firms in a difference-indifferences research design, and I estimate the following generalized specification:

$$
\text { Meet or beat }=\alpha+\beta_{1} \text { Post }+\beta_{2} \text { Treat }+\beta_{3} \text { Post }^{*} \text { Treat }+\sum_{k=1}^{K} \beta_{3+k} \text { Controls }_{k}+\varepsilon
$$

\footnotetext{
${ }^{10}$ Additionally, the fact that FAS $123 \mathrm{R}$ caused a substantial political controversy (with more than 6,500 comment letters in the deliberation process) suggests that the distinction between recognizing fair value costs and the disclosure in the footnotes matters to firms and users of financial statements.
} 
where Meet or beat is an indicator variable that equals one if the firm just met or beat an earnings target. Post is an indicator variable that equals one after the introduction of FAS 123R and zero otherwise. Similar to Hayes et al. (2012) and Bakke et al. (2016), I use 2005 as the first year of the post-FAS $123 \mathrm{R}$ period. ${ }^{11}$ Treat is an indicator variable that equals one if the firm is part of the treatment group and zero otherwise, and Controls $_{k}$ is a vector of $k$ control variables. I follow prior research (e.g., Cheng and Warfield 2005) and include a variety of variables that may correlate with beating analysts' forecasts. ${ }^{12}$ The coefficient on the interaction term $\beta_{3}$ represents the difference-in-differences estimate. Because the establishment of a causal link between option pay and opportunistic management behavior is the main contribution of this study, I employ a variety of tests to ensure a consistent and robust estimation of $\beta_{3}$.

\subsection{Data and sample}

Table 1 provides an overview of the sample selection process. The initial sample includes all firm-year observations with available data on ExecuComp, Compustat, I/B/E/S, and CRSP. I choose the three years each before (2002-2004) and after (20052007) the introduction of FAS $123 \mathrm{R}$ as my sample period. ${ }^{13}$ After merging the data, I obtain a sample of 8,145 firm-years with sufficient data for the 2002-2007 period. I exclude financial institutions with SIC codes between 6000 and 6999 because managers in these firms may have different incentives for earnings management $(-1,305$ firm-years). I also exclude utilities sector firms with SIC codes between 4400 and 5000 (-832 firm-years). Furthermore, 1,455 firm-years are excluded because of missing data for the variables. As in Hayes et al. (2012), I require that all firms have at least one observation with sufficient data in both the pre-FAS $123 \mathrm{R}$ and post-FAS $123 \mathrm{R}$ periods (-383 firm-years). The SEC changed the reporting requirements for executive compensation for fiscal years starting after December 15, 2006. This new requirement changed the way data are structured in the ExecuComp database. I follow the procedures suggested by Hayes et al. (2012) to make option pay comparable over my sample period.

My main measures are largely based on analysts' consensus forecast. Therefore, I consider only firm-years with at least five analysts included in the consensus forecast (e.g., Edmans et al. 2017). This constraint decreases the sample size to 3,256 firm-

\footnotetext{
${ }^{11}$ FAS 123R was effective starting the first fiscal quarter after June 15, 2005. Thus, a firm with a fiscal year end in July had to adopt FAS 123R starting in August 2005. The majority of firms with the fiscal year ending in December, however, had to use FAS 123R for the first time in January 2006. I still define 2005 as the first year of the post-FAS 123R period for several reasons. First, the FASB had already released a first proposal of FAS 123R in March 2004, which passed in December 2004. Therefore, I account for the possibility that firms changed their compensation schemes before FAS 123R was mandatory. Second, until April 14, 2005, FAS 123R was intended to take effect in June 2005 for all firms at the same time. The compliance date was then postponed to the start of each firm's first fiscal quarter after June 15, 2005, because of accountants' concerns about changing accounting standards during a fiscal year. Third, firms could accelerate the vesting of unvested options before adopting FAS 123R. Ladika and Sautner (2020) find that more than 700 firms, including many S\&P 1500 firms, accelerated the vesting of their unvested options. Hence, it is reasonable to assume that the effect of FAS $123 \mathrm{R}$ had already started in 2005. Nonetheless, my results and inferences are unchanged when I remove 2005 from the analyses to allow a cleaner split between the pre- and post-FAS 123R periods.

12 See Cheng and Warfield (2005, pp. 454-455) for a detailed description of all control variables.

13 The exact length of the pre- and post-windows is arbitrary. My results and inferences, however, are the same when I vary the windows from just two years prior to and after FAS 123R to up to five years (see Appendix Table A.1).
} 
Table 1 Sample selection process

Firm-years

Intersection of Compustat/CRSP/I/B/E/S/Execucomp, 2002-2007

8,145

Less:

Financial institutions and utility sector firms

Missing variables

$-1,455$

Firms without observations in both the pre- and post-event periods

$-383$

Fewer than five analysts following the firm

$-914$

Final sample

3,256

This table summarizes the sample selection process.

years. ${ }^{14}$ Of these, 310 firm-years belong to the control group, including 159 firm-years for firms that did not grant their CEOs any options from 2002 to 2004 and with 151 firm-years for firms that chose to expense options before FAS 123R. In the main tests, I use the joint control group. However, for robustness, I also employ additional analyses based on the two control groups separately. Moreover, to address the fact that control firms constitute less than $10 \%$ of the sample, I replicate my main results using randomly drawn subsamples of the treatment group. Specifically, I repeat my main test 1,000 times based on the full sample of control firms and a random sample including $10 \%$ of the treatment firm observations, which yields similar inferences. ${ }^{15}$

\subsection{Beating analysts' forecasts}

I focus on meeting or just beating analysts' consensus forecasts as a measure of opportunistic management behavior. Several studies suggest that beating analysts' forecasts is an important manifestation of earnings management (e.g., Degeorge et al. 1999; Burgstahler and Eames 2003), and many studies have shown that managers exhibit abnormal behavior around earnings targets (e.g., Burgstahler and Dichev 1997; Dhaliwal et al. 2004; Bauman et al. 2005; McVay et al. 2006; Jacob and Jorgensen 2007). According to Graham et al. (2005), most managers believe that earnings, not cash flows or revenues, are the key metric used by outsiders. Managers also consider the analyst consensus estimate to be one of the most important benchmarks, and they deem meeting or exceeding this benchmark to be very important. They believe that meeting or beating analyst forecasts builds credibility with the market and helps to increase stock prices, as "[n]ot being able to find one or two cents to hit the target might be interpreted as evidence of hidden problems at the firm" (Graham et al. 2005, p. 5). Dechow et al. (2003) also suggest that beating analysts' forecasts has become a more important hurdle than making small profits.

\footnotetext{
${ }^{14}$ When I relax this conservative restriction, the effect of option pay on beating analysts' forecasts remains similar (see Appendix Table A.2).

${ }^{15}$ For example, the firm and year fixed effects OLS regression of Column 4 in Table 4 yields a mean (median) coefficient on the Post $x$ Treat interaction term of $-0.110(-0.110)$, with a mean (median) t-statistic of -2.274 $(-2.268)$.
} 
The link between stock prices and beating analysts' forecasts is also well established in the literature. For example, Bartov et al. (2002) and Kasznik and McNichols (2002) show that the market rewards beating analysts' forecasts. Furthermore, Skinner and Sloan (2002) and Lopez and Rees (2002) provide evidence of negative price reactions when analysts' forecasts are missed. Bettis et al. (2000) show that a vast majority of firms have blackout periods in the two months before the earnings announcement date, to prevent managers from exercising options or trading the firm's stock. Consequently, option exercises or stock trades by managers take place in a narrow window after the earnings announcement, which makes potential gains or losses from these exercises or trades very sensitive to the stock price reaction to earnings announcements. Hence, managers can ultimately influence their option pay when beating analysts' forecasts.

Following prior research (e.g., Cheng and Warfield 2005), I define Meet or beat as an indicator variable that equals one if a firm's earnings per share (EPS) meets or beats analysts' consensus forecast of EPS by not more than $\$ 0.01$ (i.e., earnings surprise per share within $[\$ 0 ; \$ 0.01])$ and zero otherwise. ${ }^{16}$ I use the actual EPS as reported on $\mathrm{I} / \mathrm{B} / \mathrm{E} / \mathrm{S}$.

\section{Results}

Before I present the analysis of the effect of option pay on beating analysts' forecasts, I analyze the changes in CEOs' compensation structure around FAS 123R. This step is important to assess the characteristics of the research setting and ultimately the strength of the change in equity incentives.

\subsection{Changes in CEO compensation and incentives around FAS 123R}

Panel A of Table 2 presents the descriptive statistics for the final sample of 3,256 firm-year observations from 2002 to 2007. The mean ratio of option pay to total pay over the entire sample period is 35.6\%. Panel B of Table 2 shows separate statistics for the pre- (2002-2004) and the post-FAS 123R (20052007 ) periods. The option pay ratio decreases by approximately $35 \%$ after the adoption of FAS 123R. Panel C reports the descriptive statistics for the control and treatment groups.

Panel A of Table 3 shows the development of option pay separately for the treatment group and the two control groups. The treatment group shows a substantial decrease in mean option pay relative to total compensation, from $46.9 \%$ in the pre-FAS $123 \mathrm{R}$ period to $29.1 \%$ in the post-FAS $123 \mathrm{R}$ period. This decrease is also statistically significant at the $1 \%$ level. By contrast, for the control group of firms that have not granted any stock options in the pre-FAS 123R period (control group one), the mean ratio increases by 13 percentage points in 2005-2007. The option pay ratio of the

\footnotetext{
${ }^{16}$ My results and inferences are very similar when I define Meet or beat as an earnings surprise per share within [\$0; \$0.02]. Moreover, in the main analyses, I focus on annual earnings targets. The results and inferences, however, are similar when using quarterly earnings targets (see Appendix Table A.2).
} 
Table 2 Descriptive statistics of the sample

$\begin{array}{llllll}\begin{array}{l}\text { Panel A: Full sample } \\ \text { (firm-years=3,256) } \\ \text { (distinct firms=757) }\end{array} & & & & & \\ \text { Variable } & \text { Mean } & \text { Standard Deviation } & \text { Q1 } & \text { Median } & \text { Q3 } \\ \text { Total compensation } & 5.630 & 4.978 & 2.027 & 4.050 & 7.510 \\ \text { Delta } & 58.924 & 75.467 & 6.937 & 31.366 & 79.936 \\ \text { Vega } & 14.629 & 26.952 & 0.000 & 1.976 & 16.706 \\ \text { Option pay ratio } & 0.356 & 0.286 & 0.000 & 0.351 & 0.593 \\ \text { Salary ratio } & 0.253 & 0.215 & 0.114 & 0.184 & 0.305 \\ \text { Bonus ratio } & 0.196 & 0.161 & 0.080 & 0.168 & 0.274 \\ \text { Restricted stock ratio } & 0.125 & 0.179 & 0.000 & 0.000 & 0.232 \\ \text { LTIA ratio } & 0.067 & 0.148 & 0.000 & 0.000 & 0.000 \\ \text { Market value } & 9,097.376 & 19,242.382 & 1,112.051 & 2,695.999 & 7,977.014 \\ \text { Leverage } & 0.161 & 0.146 & 0.009 & 0.147 & 0.256 \\ \text { Return on assets } & 0.111 & 0.089 & 0.068 & 0.108 & 0.158 \\ \text { Book to market } & 0.400 & 0.262 & 0.234 & 0.343 & 0.516 \\ \text { Cash } & 0.173 & 0.175 & 0.037 & 0.107 & 0.258 \\ \text { Dividends } & 0.517 & 0.500 & 0.000 & 1.000 & 1.000 \\ \text { Investment growth } & 0.186 & 0.557 & -0.119 & 0.103 & 0.358 \\ \text { Shares } & 232.630 & 416.465 & 42.272 & 88.645 & 218.576 \\ \text { Altman-Z } & 5.464 & 4.853 & 2.727 & 4.075 & 6.374 \\ \text { CEO tenure } & 6.790 & 6.649 & 2.000 & 5.000 & 9.000 \\ \text { Number estimate } & 12.578 & 6.508 & 7.000 & 11.000 & 16.000\end{array}$

Panel B: Full sample pre- and post-FAS 123R

\begin{tabular}{lllll} 
& \multicolumn{2}{l}{ Pre-FAS 123R (2002-2004) } & \multicolumn{2}{l}{ Post-FAS 123R (2005-2007) } \\
Variable & Mean & Median & Mean & Median \\
Total compensation & 5.347 & 3.741 & 5.885 & 4.219 \\
Delta & 59.289 & 33.485 & 58.595 & 28.109 \\
Vega & 19.251 & 5.463 & 10.472 & 0.054 \\
Option pay ratio & 0.436 & 0.465 & 0.284 & 0.260 \\
Salary ratio & 0.262 & 0.189 & 0.245 & 0.182 \\
Bonus ratio & 0.185 & 0.161 & 0.206 & 0.177 \\
Restricted stock ratio & 0.075 & 0.000 & 0.171 & 0.116 \\
LTIA ratio & 0.041 & 0.000 & 0.091 & 0.000 \\
Market value & $8,350.234$ & $2,291.846$ & $9,769.542$ & $2,994.945$ \\
Leverage & 0.168 & 0.159 & 0.155 & 0.138 \\
Return on assets & 0.102 & 0.102 & 0.119 & 0.113 \\
Book to market & 0.410 & 0.349 & 0.390 & 0.336 \\
Cash & 0.178 & 0.112 & 0.168 & 0.105 \\
Dividends & 0.494 & 0.000 & 0.538 & 1.000
\end{tabular}


Table 2 (continued)

\begin{tabular}{lllll}
\hline Investment growth & 0.139 & 0.041 & 0.228 & 0.147 \\
Shares & 231.183 & 85.610 & 233.932 & 91.085 \\
Altman-Z & 5.593 & 4.001 & 5.348 & 4.140 \\
CEO tenure & 6.754 & 5.000 & 6.822 & 5.000 \\
Number estimate & 12.645 & 11.000 & 12.518 & 11.000 \\
Observations & 1,542 & 1,542 & 1,714 & 1,714
\end{tabular}

Panel C: Treatment and control groups

\begin{tabular}{|c|c|c|c|c|}
\hline \multirow[b]{2}{*}{ Variable } & \multicolumn{2}{|c|}{$\begin{array}{l}\text { Treatment group } \\
\text { (unique firms }=687 \text { ) }\end{array}$} & \multicolumn{2}{|c|}{$\begin{array}{l}\text { Control group } \\
\text { (unique firms }=70 \text { ) }\end{array}$} \\
\hline & Mean & Median & Mean & Median \\
\hline Total compensation & 5.643 & 4.071 & 5.505 & 3.618 \\
\hline Delta & 59.597 & 32.465 & 52.530 & 18.094 \\
\hline Vega & 15.022 & 2.485 & 10.896 & 0.000 \\
\hline Option pay ratio & 0.375 & 0.373 & 0.178 & 0.000 \\
\hline Salary ratio & 0.242 & 0.182 & 0.359 & 0.234 \\
\hline Bonus ratio & 0.192 & 0.165 & 0.231 & 0.204 \\
\hline Restricted stock ratio & 0.124 & 0.000 & 0.140 & 0.000 \\
\hline LTIA ratio & 0.065 & 0.000 & 0.089 & 0.000 \\
\hline Market value & $8,269.102$ & $2,702.872$ & $16,968.644$ & $2,677.064$ \\
\hline Leverage & 0.161 & 0.145 & 0.163 & 0.155 \\
\hline Return on assets & 0.110 & 0.108 & 0.122 & 0.111 \\
\hline Book to market & 0.396 & 0.341 & 0.430 & 0.366 \\
\hline Cash & 0.176 & 0.111 & 0.142 & 0.084 \\
\hline Dividends & 0.494 & 0.000 & 0.735 & 1.000 \\
\hline Investment growth & 0.186 & 0.101 & 0.184 & 0.113 \\
\hline Shares & 219.327 & 88.156 & 359.047 & 90.451 \\
\hline Altman-Z & 5.436 & 4.088 & 5.729 & 3.901 \\
\hline CEO tenure & 6.553 & 5.000 & 9.042 & 5.000 \\
\hline Number estimate & 12.628 & 11.000 & 12.106 & 10.000 \\
\hline Observations & 2,946 & 2,946 & 310 & 310 \\
\hline
\end{tabular}

This table presents descriptive statistics. See Appendix 1, Table 8 for variable definitions. 

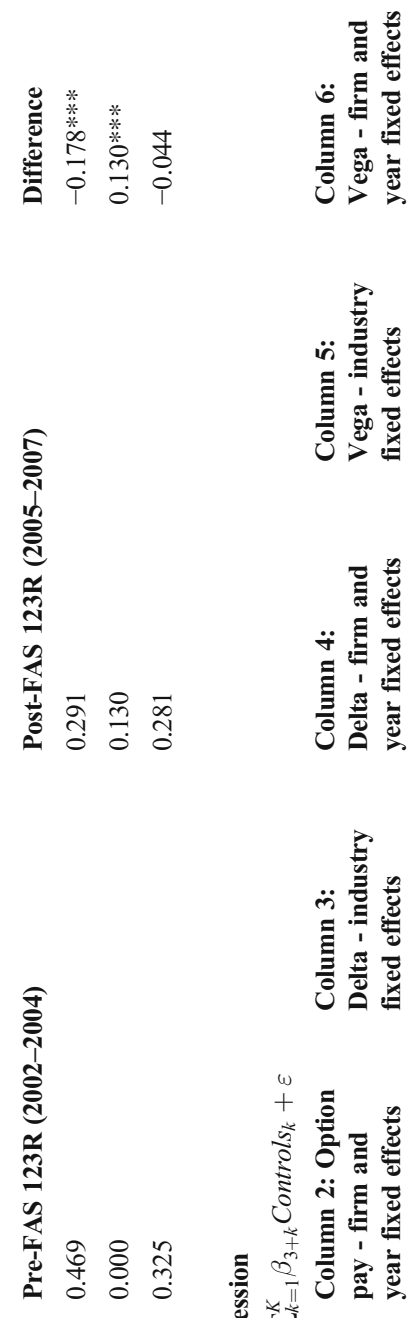

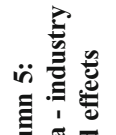

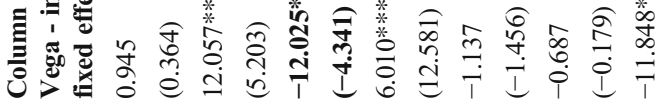
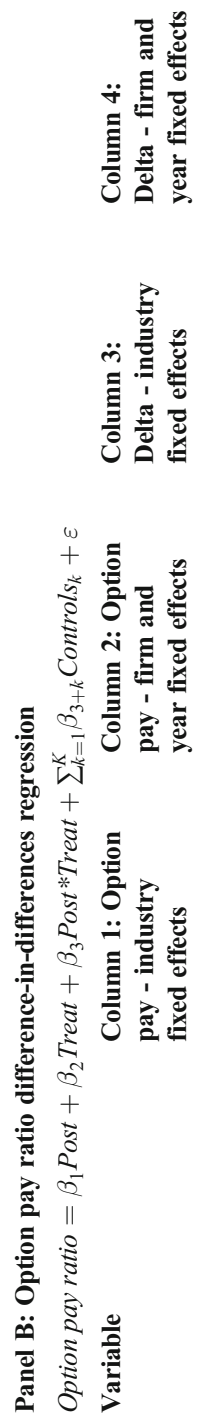

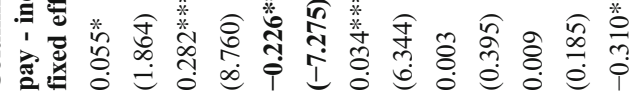

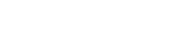




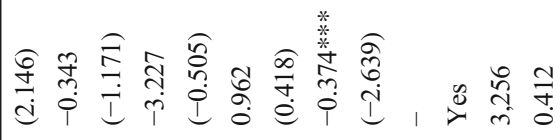

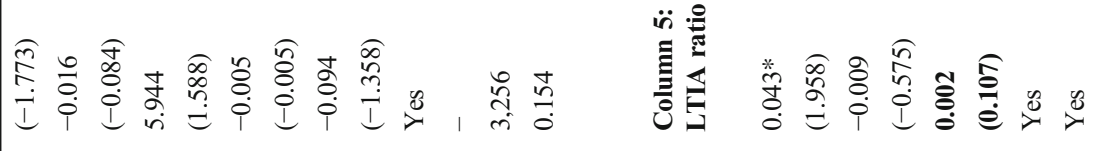

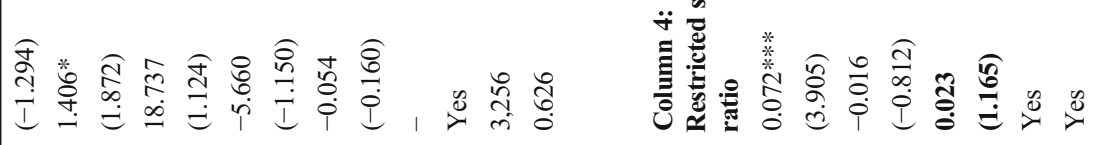

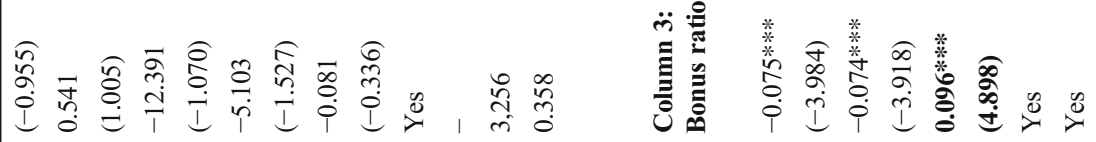

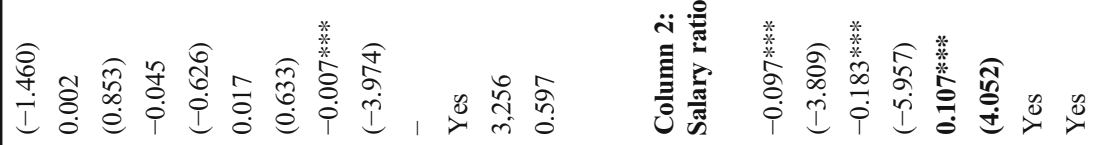

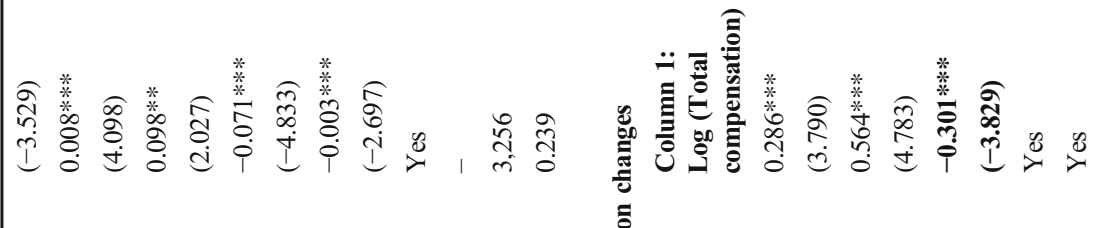

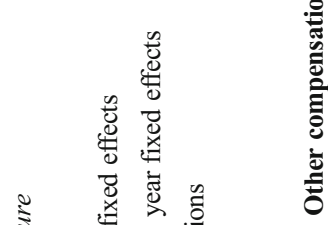

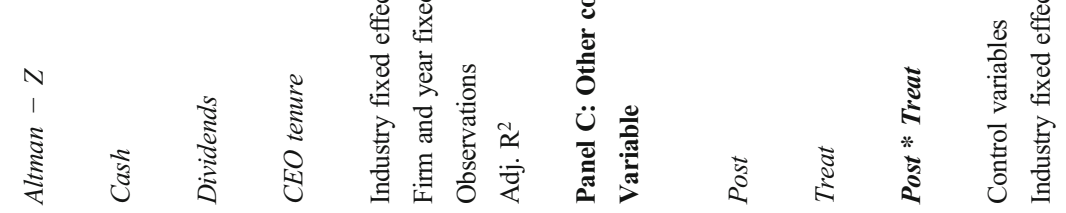




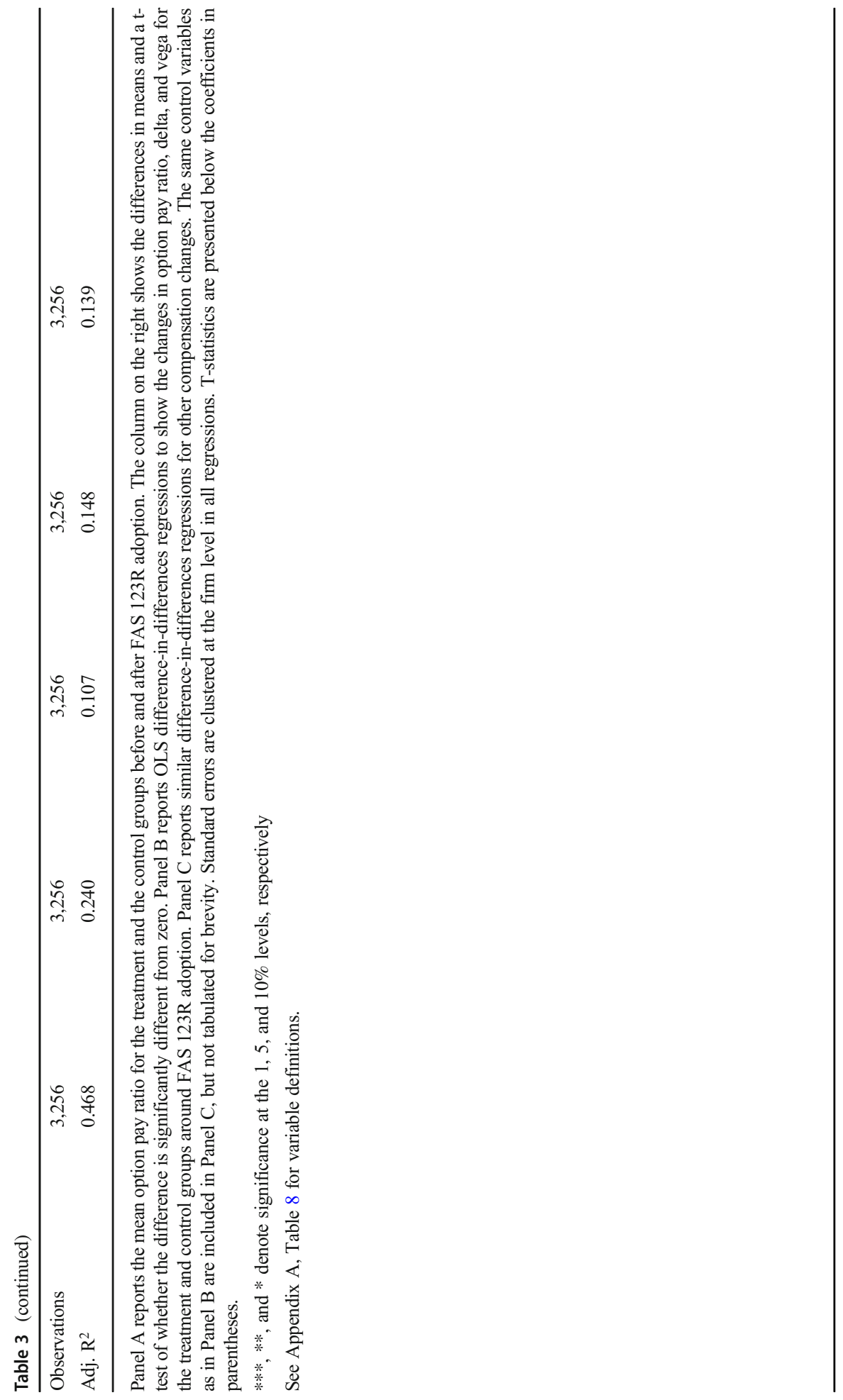


control group two (i.e., firms that already opted to expense options in the pre-FAS 123R period) shows a nonsignificant decrease of 4.4 percentage points. ${ }^{17}$

Panel B of Table 3 reports difference-in-differences OLS regressions with the option pay ratio as the dependent variable. ${ }^{18} \mathrm{I}$ also investigate the related changes in the sensitivity of CEO annual pay to changes in the stock price (Delta) and sensitivity to stock price volatility (Vega). ${ }^{19}$ I focus on the Delta and Vega of current grants during the six-year sample period because I am particularly interested in changes to executive incentives after FAS $123 \mathrm{R}$ adoption. ${ }^{20}$ In contrast to Delta and Vega from all prior grants, current grants reflect the fraction of outstanding compensation that is directly under the control of the board of directors (Hayes et al. 2012). Hence, potential reactions and adjustments in the compensation structure by the board are more readily observable. ${ }^{21}$ I cluster standard errors at the firm level in all specifications.

In Column 1, firm- and CEO-level controls suggested by prior research (e.g., Bakke et al. 2016) and industry fixed effects are included. The coefficient on Post $*$ Treat shows that the ratio of stock option pay to total compensation for treated firms decreases on average by 22.6 percentage points in comparison with the ratio for the joint control group. This result holds when I use firm and year fixed effects in Column 2. This substantial decrease in option pay for the treated firms shows the compelling effect of FAS 123R on option pay. As shown in Column 3 (Column 4), firms affected by FAS 123R also experience an average Delta decline of 32.244 (27.171), compared with the control group. Hence, their payperformance sensitivity declined by more than $50 \%$ from the sample mean, which is highly meaningful in terms of economic magnitude. For the mean CEO, FAS 123R results in forgone compensation of approximately $\$ 90,000$ for a hypothetical increase in the stock price of $\$ 1$ in any given year. ${ }^{22}$ Unsurprisingly, as reported in Column 5 (Column 6), the

\footnotetext{
${ }^{17}$ In robustness tests, I restrict the first control group to firms that did not have any option grants in the pre- and in the post-FAS 123R periods. This approach does not change the inferences obtained (see Column 3 of Appendix Table A.4).

${ }^{18}$ Because the option pay ratio is censored between 0 and 1 , a nonlinear model would generally be appropriate. I use an OLS model instead because a difference-in-differences model with fixed effects may cause incidental parameter problems in nonlinear models.

${ }^{19}$ Delta reflects the change in annual equity-based compensation for a $1 \%$ change in the stock price, and Vega represents the change in annual equity-based compensation for a 0.01 change in stock price volatility. To measure Delta and Vega, I follow the existing literature (e.g., Guay 1999; Coles et al. 2006; Hayes et al. 2012). Appendix A, Table 8 provides details on the variable definition and construction.

${ }^{20}$ Note that a change in grants of options that take several years to fully vest may still impact managers' current incentives in the post-period: Given that the post-period is three years, an average option grant that takes three years to fully vest (e.g., Hall and Murphy 2002) would affect the post sample period in my difference-in-differences tests. Moreover, partial vesting is very common, meaning that parts of a grant already become exercisable earlier. In this regard, Aboody (1998) shows that 94\% (97\%) of option plans partially vest (with at least 20\%) within the first year (first two years). Hence, this partial vesting creates immediate incentive changes caused by changes in current grants. Moreover, as noted before, the FASB had already released a first proposal of FAS 123R in March 2004, which passed in December 2004. Therefore, some firms already changed their compensation schemes before FAS 123R was mandatory, which increases the likelihood that changes in grants caused by FAS 123R would affect my post sample period. Finally, options granted before FAS 123R that would become exercisable in the post-period are affected as well, because firms could accelerate the vesting of unvested options before adopting FAS 123R (Jochem et al. 2018; Ladika and Sautner 2020). This accelerated vesting in the pre-FAS $123 \mathrm{R}$ period creates a much more pronounced change in equity incentives around the introduction of FAS 123R.

${ }^{21}$ Moreover, most firms chose prospective adoption (McConnell et al. 2006), which only affected the accounting of new option grants and unvested options. This approach, however, is subject to an important limitation. Specifically, focusing on option grants may underestimate any effect, because equity incentives are also affected by the current holdings.

${ }^{22}$ A $1 \%$ change in the mean stock price of $\$ 35.43$ reflects $\$ 0.35$; scaled to $\$ 1$, this leads to Delta $*(1 / 0.35)=\$ 92,126$.
} 
sensitivity of CEO compensation to stock price volatility ( $\mathrm{Vega}$ ) also decreased significantly, by 12.025 (11.380); this is also economically meaningful, considering that the mean Vega in the pre-FAS 123 period is 19.251 .

Next, I analyze how FAS 123R affects various other components of CEO compensation. This analysis allows me to assess how firms adjust their compensation structure around FAS 123R. I use a difference-in-differences regression similar to the one in Panel B of Table 3 to analyze changes in total compensation and the proportion of the different components relative to total compensation. This analysis of the effect of FAS 123R on CEOs' compensation structure replicates a similar analysis in Hayes et al. (2012). In contrast to the pre-/post-FAS 123R specification of Hayes et al. (2012), I include a control group and a variety of additional control variables to better isolate the effect of FAS 123R from concurrent development and changes in compensation related to changes in other firm characteristics known to be associated with CEO compensation. Column 1 in Panel C of Table 3 reports the results with the log of total compensation as the dependent variable. While Hayes et al. (2012) document an average increase in total compensation of approximately 15 percentage points after FAS $123 \mathrm{R}$, my results are substantially different. I find that firms not directly affected by FAS 123R show a mean increase of approximately 29 percentage points, whereas firms affected by FAS 123R even show a marginal decrease of 1.5 percentage points (as measured by the sum of the Post coefficient and the interaction term Post $*$ Treat coefficient). ${ }^{23}$ Hence, firms that experienced a decrease in option pay as a result of FAS 123R did not sufficiently substitute other forms of compensation for stock options to maintain a similar level of compensation, let alone to keep up with the development of firms not directly affected by FAS $123 \mathrm{R}$.

Columns 2-5 shed additional light on the mean substitution of other forms of compensation. Unsurprisingly, both the ratio of fixed salary to total compensation and the ratio of bonus pay to total compensation significantly increases, by approximately 10 percentage points, for treatment firms compared with control firms. Untabulated results, however, show that the average level of salary and bonuses remains virtually the same. The increase in the proportion of salary and bonus occurs largely because the decrease in option pay gives more weight to the other compensation components. In contrast to Hayes et al. (2012), I do not find that firms on average substituted option pay with other forms of pay-performance sensitive compensation, such as restricted stock; nor do I find an increase in long-term incentive awards. These results suggest that the compensation of the average firm was not sufficiently adjusted. Compared to CEOs in firms that were not directly affected by FAS 123R, CEOs in the treatment firms received substantially less compensation and, in particular, less payperformance-sensitive forms of compensation.

In summary, consistent with prior research (e.g., Brown and Lee 2011; Hayes et al. 2012), I find a substantial decrease in option pay resulting from FAS 123R. My results, however, do not support the notion that FAS 123R leads to a substitution of option pay with restricted stock, as documented by Hayes et al. (2012). Instead, I find that, on average, firms do not adjust to FAS 123R to maintain similar levels of pay-performance sensitivity and sensitivity to stock price volatility. Because Hayes et al. (2012) run a pre-/post-FAS 123R regression while I use a difference-in-differences analysis with a control group, I believe

\footnotetext{
${ }^{23}$ When I run a pre-/post-FAS 123R regression for all firms as in Hayes et al. (2012), I also find an average increase in total compensation of approximately 15 percentage points.
} 
that my design better captures the effect of FAS 123R on compensation. Moreover, the results are also consistent with the insufficient substitution of option pay with restricted stock and long-term incentive plans, as shown by Brown and Lee (2011).

\subsection{Effect of option pay on beating analysts' targets.}

Next, I exploit this substantial change in option pay and executive incentives to test whether it leads to a change in beating analysts' targets. I estimate a logit model with beating analysts' targets on the left-hand side and include several control variables suggested by prior research (e.g., Cheng and Warfield 2005). Variable definitions are provided in Appendix 1, Table 8. As discussed before, I use a difference-in-differences specification with Post, Treat, and their interaction. The interaction variable Post * Treat is my primary variable of interest because it measures the extent to which beating analysts' targets changes after the decline in option pay. Table 4 reports the results with the coefficient estimates and zstatistics in parentheses. I also report the regular logit marginal effect for all variables. Marginal effects of continuous independent variables are computed at the means; for the dummy variables, they represent the change in value from 0 to 1 . According to Ai and Norton (2003), there is a debate on the interpretation of coefficient estimates on interaction terms from nonlinear models such as logit models. To ensure valid inferences on the interaction term, I also follow the procedure recommended by Ai and Norton (2003) and Norton et al. (2004). Specifically, I compute the mean marginal effect and z-statistic of the interaction term for each of my 3,256 observations. ${ }^{24}$ To further address the potential concern of incidental parameter problems resulting from fixed effects in non-linear models, I also present the main results of using a linear probability model.

In Table 4, I report the baseline specification without controls in Column 1 and with controls in Column 2. In Column 3, I include firm and year fixed effects. ${ }^{25}$ Column 4 shows the linear probability model with firm and year fixed effects and standard errors clustered at the firm level. The interaction term is consistently negative and highly significant in all specifications, with the regular marginal effect ranging from $14 \%$ to $20 \%$. Hence, with other variables held at their means, the likelihood of beating analysts' targets decreases by up to $20 \%$ for the treatment group after the decline in option pay. ${ }^{26}$ The magnitude of this effect is highly meaningful in economic terms. The results are similar when I use the procedures of $\mathrm{Ai}$ and Norton (2003) and Norton et al. (2004). ${ }^{27}$ The finding that the magnitude and significance of the interaction term increase when I include more firm-level and CEO control

\footnotetext{
${ }^{24}$ As suggested by Ai and Norton (2003) and Greene (2010), I also supplement this analysis with graphical evidence of the z-statistics of the interaction effect for each observation of my sample. The distribution shows that the zstatistics are reliably negative across all sample observations, which is consistent with the negative sign on the coefficient estimate. Moreover, the vast majority of the z-statistics are statistically significant at conventional levels. ${ }^{25}$ Note that the number of observations decreases in this specification. Conditional fixed effects logit models consider within-subject variability. Firms that do not show any variability in the dependent variable during the six-year sample period are automatically omitted from the analysis.

${ }^{26}$ This finding may seem at odds with the result of Quinn (2018), who finds a decline in meeting or beating analysts' forecasts after the initiation of equity ownership plans. However, the initiation of equity ownership plans rather functions as a restriction of realizing potential gains from existing or concurrent stock-compensation (until the prescribed level of stock ownership is reached). Hence, the effect of these plans is a decrease in realizable short-term equity-based compensation; thus, the decline in meet or beat after the initiation of stock ownership plans in Quinn (2018) is consistent with my finding of a decrease in meet or beat after a decline in option pay.

${ }^{27}$ Note that the Ai and Norton (2003) and Norton et al. (2004) method cannot be used with the firm fixed effects logit regressions in Column 3.
} 


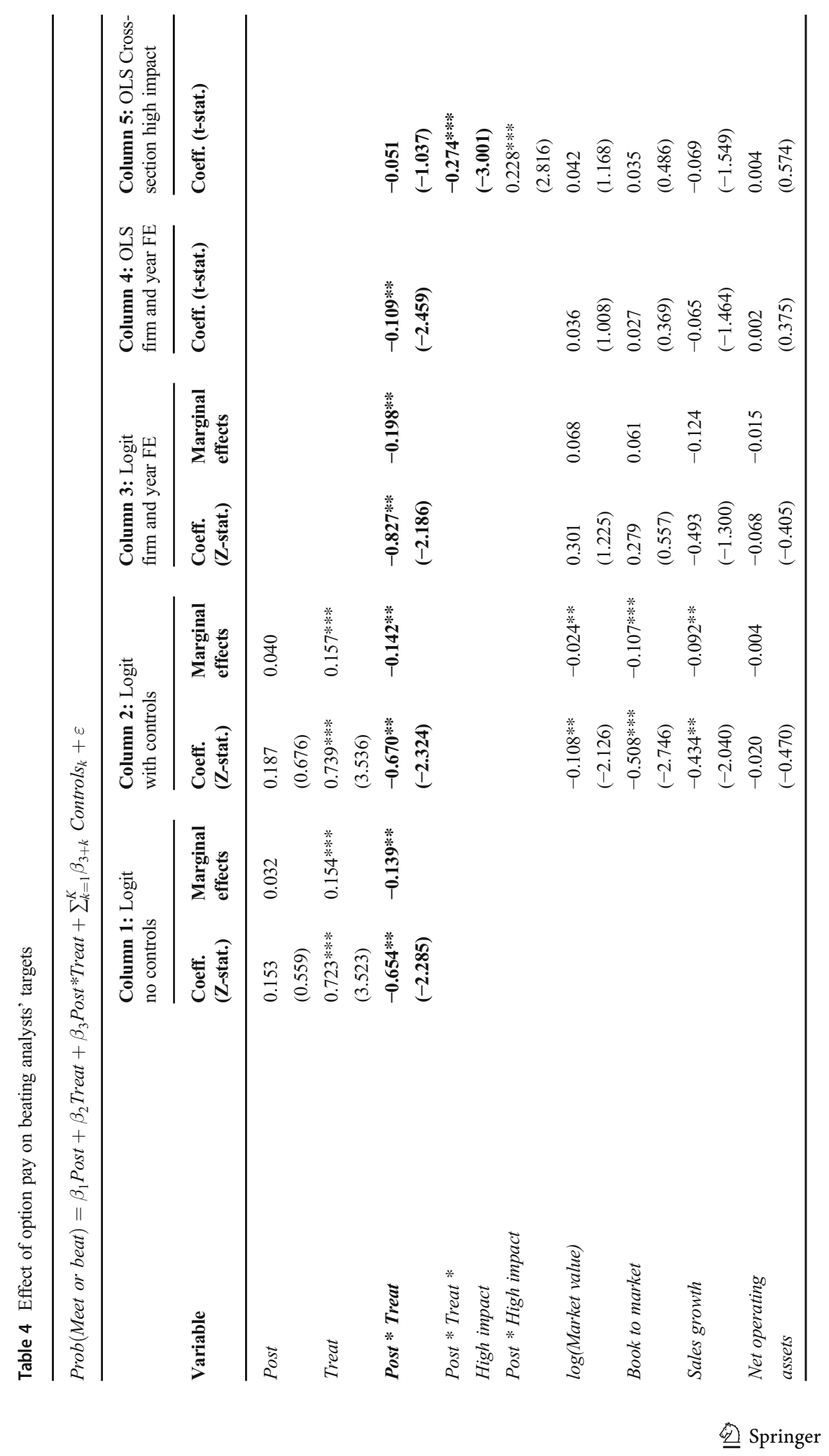




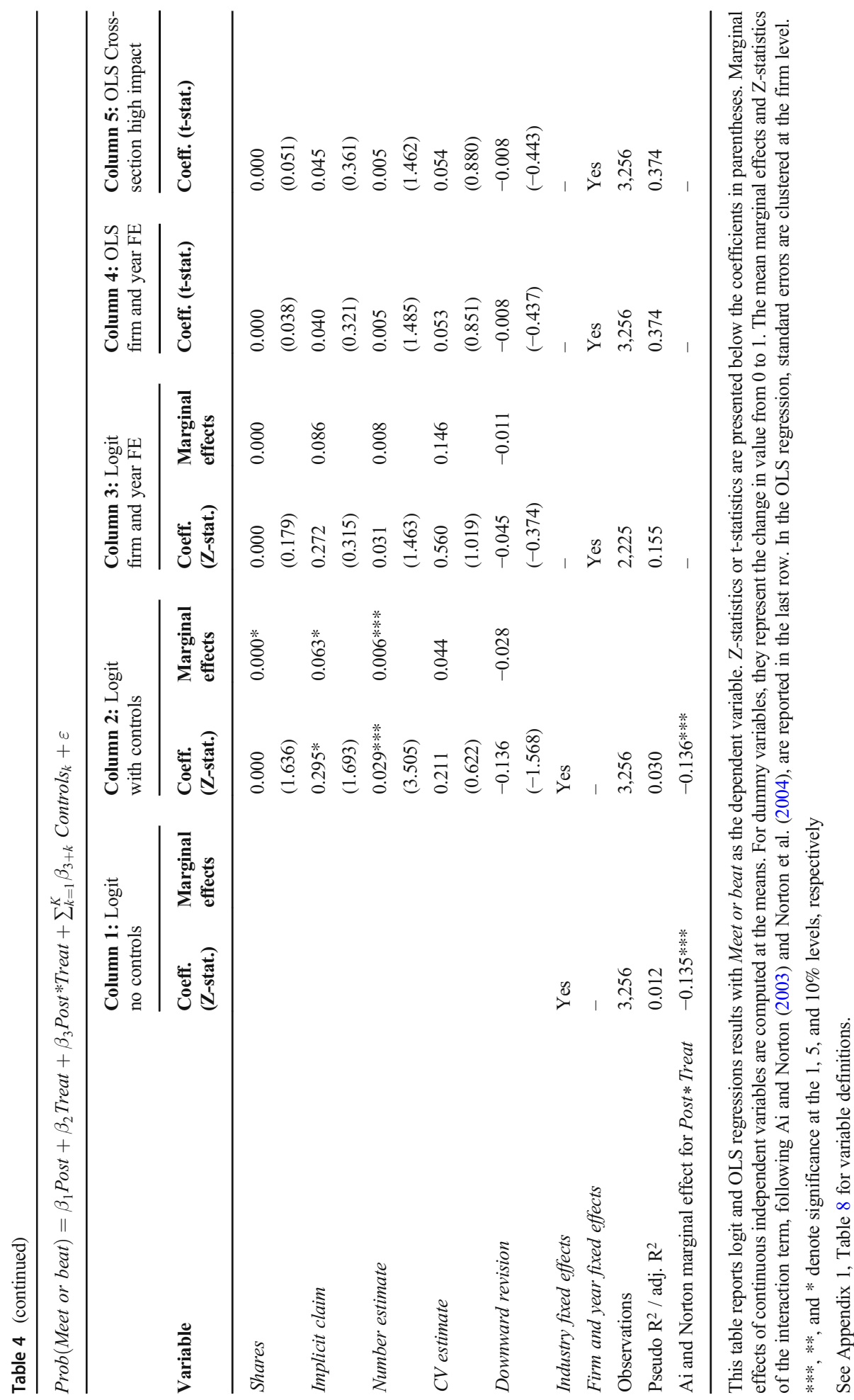


variables supports the notion that the assignment of the treatment is not highly correlated with observable firm and CEO characteristics.

Next, I exploit some cross-sectional variation in the treatment group to bolster confidence in the main effect. Specifically, FAS 123R affected some firms more than others, depending on the firm-specific expected accounting impact. Following Ferri and Li (2018), I measure the accounting impact by the implied option expense disclosed in the footnotes prior to FAS $123 \mathrm{R}^{28}$ I use the implied option expense in 2002 to avoid any confounding effects from the expected adoption of FAS $123 \mathrm{R}$ and thus to focus on the exogenous portion of a firm's response to FAS 123R (Ferri and Li 2018). I introduce a dummy variable, High impact, that equals one for treatment firms that show an above median absolute implied option expense. ${ }^{29}$ I include the triple interaction term Post * Treat * High impact and further interactions of High impact in a firm and year fixed effects OLS regression similar to the one in Column 4. The results in Column 5 show that the decrease in beating analysts' targets is significantly stronger for firms that have a higher expected accounting impact of FAS 123R. Specifically, while the main effect of Post * Treat is still negative $(-0.051)$, the incremental decline in beating analysts' targets for High impact firms is significantly stronger, as indicated by the triple interaction term of -0.274 . This result supports the notion that the change in option pay drives the change in beating analysts' targets.

\subsection{Threats to the identification and robustness tests}

\subsubsection{Pre-FAS 123R differences}

The main challenge for my identification strategy is the nonrandom assignment of firms to the treatment and control groups. Anything that drives the decision to voluntarily expense options or to not grant any options before FAS 123R, which also affects beating analysts' targets after FAS 123R may bias the results. This potential bias is more likely if the treated and control firms are fundamentally different prior to FAS 123R. To address this concern, I compare fundamental firm characteristics between the two groups before FAS 123R. Panel A of Table 5 presents t-tests of the mean comparisons of several firm-level variables. The results show that the differences in means are statistically nonsignificant for all variables except size, profitability, and cash holdings. This similarity between the treated and control firms before FAS 123R provides some confidence that my results are not driven by unobservable differences between the treatment and control groups.

To further alleviate this concern, however, I employ PSM. I match the treatment and control firms in the pre-FAS 123R period based on the fundamental firm characteristics reported in Panel A of Table 5. I require a maximum caliper range of 0.01 ; that is, only firms with a maximum difference of 0.01 in the propensity scores are matched. Moreover, I use one-to-one matching without replacement over the common support region. PSM results in 574 firm-years of matched treatment and control firms. ${ }^{30}$ First, I ensure covariate balance

\footnotetext{
28 The implied option expense is the fair value amount of options that firms would have to expense after FAS 123R.

${ }^{29}$ I scale the implied option expense by the absolute amount of EBIT. Scaling by total assets provides similar results and inferences.

${ }^{30}$ The conservative matching requirements lead to relatively few matches. When I allow a wider caliper range or relax the common support region requirement, I find substantially more matched pairs. Based on these larger samples, the results and inferences are similar.
} 
Table 5 Selection bias validity tests

$\begin{array}{lllll}\text { Panel A: Pre-FAS 123R differences } & & & \\ \text { Variable } & \text { Mean treated } & \text { Mean control } & \text { Difference } & \text { p value } \\ \text { log(Market value }) & 7.867 & 8.282 & -0.415^{* * * *} & 0.001 \\ \text { Leverage } & 0.168 & 0.169 & -0.001 & 0.947 \\ \text { Return on assets } & 0.101 & 0.115 & -0.014^{*} & 0.065 \\ \text { Book to market } & 0.406 & 0.443 & -0.037 & 0.112 \\ \text { Sales growth } & 1.127 & 1.124 & 0.003 & 0.868 \\ \text { Cash } & 0.180 & 0.153 & 0.027^{*} & 0.076 \\ \text { Investment growth } & 0.140 & 0.129 & 0.011 & 0.816 \\ \text { Implicit claim } & 0.478 & 0.437 & 0.041 & 0.167 \\ \text { Altman-Z } & 5.546 & 6.001 & -0.455 & 0.306 \\ \text { Number estimate } & 12.708 & 12.100 & 0.608 & 0.273 \\ \text { Observations } & 1,382 & 160 & & \end{array}$

Panel B: Propensity score matched sample

Column 1: Logit PSM

\begin{tabular}{|c|c|c|}
\hline Variable & Coeff. (Z-stat.) & Marginal effects \\
\hline \multirow[t]{2}{*}{ Post } & 0.105 & 0.020 \\
\hline & $(0.333)$ & \\
\hline \multirow[t]{2}{*}{ Treat } & $0.878 * * *$ & $0.106^{* * * *}$ \\
\hline & $(2.890)$ & \\
\hline \multirow[t]{2}{*}{ Post $*$ Treat } & $-1.187 * * *$ & $-0.224 * *$ \\
\hline & $(-2.866)$ & \\
\hline Controls & Yes & \\
\hline Industry fixed effects & Yes & \\
\hline Observations & 574 & \\
\hline Pseudo $\mathrm{R}^{2}$ / adj. $\mathrm{R}^{2}$ & 0.128 & \\
\hline
\end{tabular}

Column 2: OLS PSM

Coeff. (t-stat.)

0.016

(0.331)

$0.175 * * *$

$-0.223 * * *$

$(-2.998)$

Yes

Yes

574

0.146

Panel A reports the means of several fundamental firm characteristics for the treatment and control groups in the pre-FAS $123 \mathrm{R}$ period. $P$-values for t-tests comparing the differences in means between the two groups are reported in the right column.

Panel B presents industry fixed effects regressions based on the propensity score-matched sample. Z-statistics or t-statistics are presented below the coefficients in parentheses. Marginal effects of dummy variables represent the change in value from 0 to 1 . The same control variables as in Table 3 are included but not tabulated for brevity. In the OLS regression, standard errors are clustered at the firm level.

$* * *, * *$, and $*$ denote significance at the 1,5 , and $10 \%$ levels, respectively

See Appendix 1 for variable definitions.

along all fundamental firm characteristics. Then, I validate my analyses based on the matched sample. Panel B of Table 5 reports the results. Column 1 shows a logit regression with firm industry fixed effects, and Column 2 shows an OLS regression with industry fixed effects and standard errors clustered at the firm level. The results and inferences are economically very similar to the results based on the full sample and are statistically significant at the $1 \%$ level. 


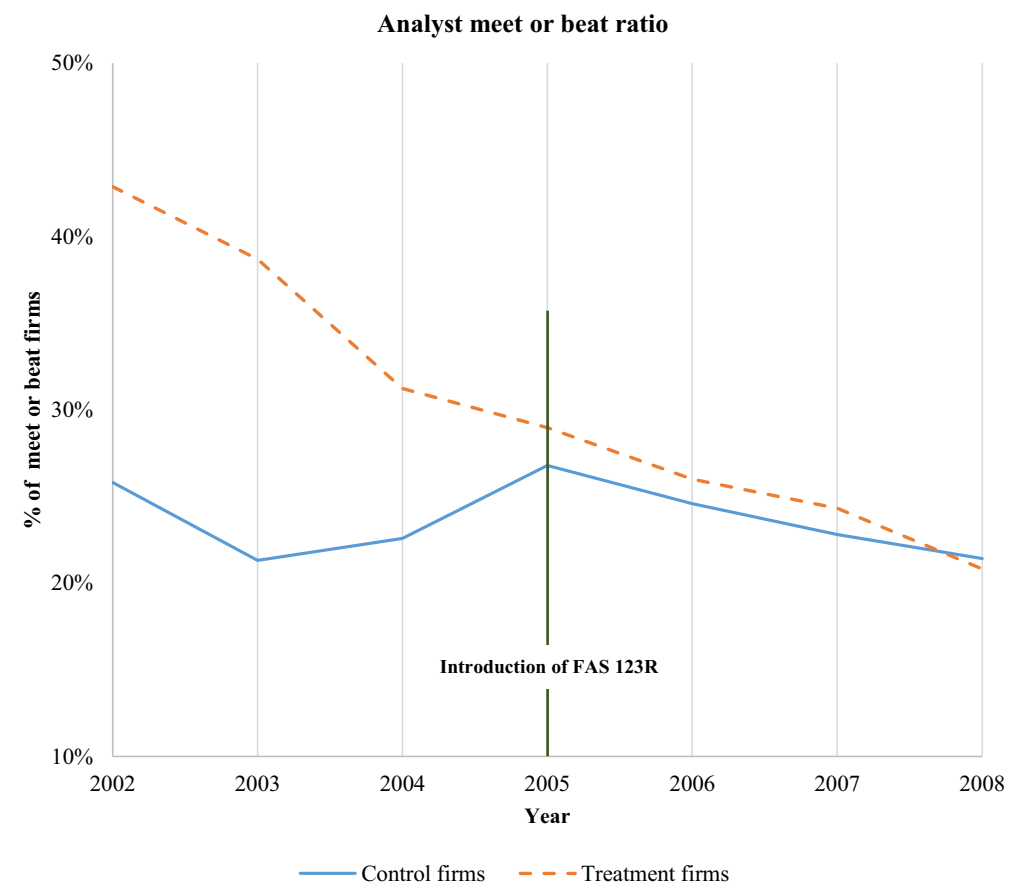

Fig. 1 Analyst meet or beat ratio

\subsubsection{Parallel trends assumption}

The key identifying assumption of difference-in-differences designs is the parallel trends condition. That is, in the absence of a treatment, the treatment and control firms would have continued on parallel trends. To assess whether this assumption may be violated, I conduct three analyses. First, I graphically analyze the trends in beating analysts' targets. In Fig. 1, I plot the fraction of firms that meet or beat analyst forecasts for the treatment and control groups over time. ${ }^{31}$ Although the level of beating analysts' targets is substantially higher for the treatment group before FAS 123R, the trend from 2002 to 2003 is similar. In 2004, the two groups start to converge. ${ }^{32}$ After 2005, the treatment and control groups show virtually similar trends. ${ }^{33}$

Second, I check whether the treatment and control firms show any concurrent changes in other fundamental firm characteristics. Panel A of Table 6 reports several firm and year fixed effects difference-in-differences OLS regressions, with the variables

\footnotetext{
${ }^{31}$ I provide the same figure for the PSM sample in the web appendix (Fig. A.2).

32 Note that some firms started to cut option pay in 2004, when FAS $123 \mathrm{R}$ was issued. Hence, some of the effects of FAS 123R may have started earlier than 2005. To test whether this issue violates the parallel trends assumption, I follow Angrist and Pischke (2008) and empirically test the assumption using leads and lags of the treatment effect. Appendix Table A.5 shows that all pre-treatment interaction terms are nonsignificant, supporting the parallel trends assumption.

${ }^{33}$ It may be surprising that treatment and control firms converge to the same level of beating analysts' targets after FAS 123R (although some differences in the option pay ratio remain). However, note that the differences in delta and vega incentives become economically small and insignificant in the post-FAS $123 \mathrm{R}$ period (untabulated).
} 
Table 6 Common trends and other validity tests

Panel A: Firm and year fixed effects difference-in-differences regressions of fundamentals

\begin{tabular}{llll}
\hline Dependent variable & Post $*$ Treat & t-stat. & adj. $\mathbf{R}^{\mathbf{2}}$ \\
log(Market value) & 0.007 & 0.163 & 0.958 \\
Leverage & 0.012 & 1.237 & 0.783 \\
Return on assets & 0.003 & 0.571 & 0.786 \\
Sales growth & 0.018 & 0.752 & 0.386 \\
Cash & -0.003 & -0.356 & 0.887 \\
Investment growth & -0.023 & -0.335 & 0.246 \\
Implicit claim & 0.004 & 0.474 & 0.966 \\
Altman-Z & -0.170 & -0.597 & 0.834 \\
Number estimate & 0.072 & 0.217 & 0.876
\end{tabular}

Panel B: Pseudo-events and other tests

\begin{tabular}{|c|c|c|c|c|}
\hline Variable & $\begin{array}{l}\text { Column 1: } \\
\text { Pseudo event } 2007\end{array}$ & $\begin{array}{l}\text { Column 2: } \\
\text { Control group } 1 \text { vs. } \\
\text { Control group } 2\end{array}$ & $\begin{array}{l}\text { Column 3: } \\
\text { Only control } \\
\text { group } 1\end{array}$ & $\begin{array}{l}\text { Column 4: } \\
\text { Only control } \\
\text { group } 2\end{array}$ \\
\hline Post & $\begin{array}{l}-0.006 \\
(-0.115)\end{array}$ & $\begin{array}{l}0.010 \\
(0.129)\end{array}$ & $\begin{array}{l}0.029 \\
(0.532)\end{array}$ & $\begin{array}{l}0.031 \\
(0.543)\end{array}$ \\
\hline Treat & $\begin{array}{l}0.037 \\
(1.200)\end{array}$ & $\begin{array}{l}0.132 \\
(1.340)\end{array}$ & $\begin{array}{l}0.141^{* * * *} \\
(2.928)\end{array}$ & $\begin{array}{l}0.142 * * * \\
(2.805)\end{array}$ \\
\hline Post $*$ Treat & $\begin{array}{l}-0.009 \\
(-0.183)\end{array}$ & $\begin{array}{l}-0.037 \\
(-0.353)\end{array}$ & $\begin{array}{l}-0.131 * * \\
(-2.322)\end{array}$ & $\begin{array}{l}-0.132 * * \\
(-2.199)\end{array}$ \\
\hline Controls & Yes & Yes & Yes & Yes \\
\hline Industry fixed effects & Yes & Yes & Yes & Yes \\
\hline Observations & 3,445 & 310 & 3,097 & 3,105 \\
\hline Adj. $R^{2}$ & 0.063 & 0.245 & 0.062 & 0.062 \\
\hline
\end{tabular}

Panel A shows the coefficient and t-statistic of the interaction term in OLS firm and year fixed effects difference-in-differences regressions for fundamental firm characteristics. Panel B reports OLS industry fixed effects regressions of pseudo and other tests. The same control variables as in Table 3 are included, but not tabulated for brevity. T-statistics are presented below the coefficients in parentheses. All regressions include standard errors clustered at the firm level

$* * *, * *$, and $*$ denote significance at the 1,5 , and 10 percent levels, respectively

See Appendix A for variable definitions

used in Panel A as dependent variables. ${ }^{34}$ The interaction coefficient Post * Treat is my primary variable of interest. This coefficient represents whether the treatment firms start to become fundamentally different along several dimensions that may, apart from option pay, also influence beating analysts' targets behavior. The results show that none of the interactions are significant, which supports the notion that my results are likely not biased by concurrent changes in fundamental firm characteristics.

To provide further support that the parallel trends condition holds, I employ a placebo test, as suggested by Roberts and Whited (2013). I maintain the same treatment

\footnotetext{
$\overline{34}$ The results and inferences are similar when I use only industry fixed effects.
} 
and control groups but use the year 2007 as a placebo event. I run a similar regression as in my main tests, with 2005-2006 as the pre-event period and 2007-2008 as the post-event period. For brevity, I report only the OLS regressions. The results and inferences, however, remain unchanged when I use logit models. Column 1 in Panel B of Table 6 shows that there is no effect of the placebo event in 2007.

\subsubsection{Further placebo tests}

Next, I use control group one (i.e., firms that did not issue options before FAS 123R) as a pseudo-treatment group and control group two (i.e., firms that voluntarily expensed the fair value of options before FAS 123R) as the control group to test whether there is a differential change in beating analysts' targets between the two control groups from the pre-FAS $123 \mathrm{R}$ to the post-FAS $123 \mathrm{R}$ period. Because both groups are largely unaffected by FAS 123R, I should not observe any differential effect. However, if unobserved differences between my treatment and control groups that are associated with either the decision to grant or the decision to expense options before FAS 123R drive my main results, these differences should also occur between the two control groups. Hence, in this case, I should observe a differential effect between the two groups. However, as reported in Column 2 in Panel B of Table 6, I do not find any differential change in beating analysts' targets between the two control groups.

I further exploit the fact that I have two control groups. These groups differ from each other because one did not grant any options at all before FAS 123R and the other chose to expense their options. Because of these differences, any potential biases arising from pre-treatment differences in the control groups are mitigated. In Columns 3 and 4 in Panel B of Table 6, I find similar results when I replicate my analyses using each control group separately. Hence, my main results are unlikely to be contaminated by either bias.

Similarly, I exploit the fact that the reasons for voluntarily opting the fair value method in the second control group likely differ between early and late voluntary adopters. As elaborated previously, some firms were pioneers in voluntarily expensing options, while others (the late adopters) likely followed owing to peer pressure or anticipation of FAS 123R. In untabulated tests, I rerun all analyses while excluding either early adopters that expensed options in 2002 (or before) or late adopters that started to expense options in 2003. Again, the results and inferences remain very similar, indicating that there is no bias from pre-treatment differences associated with the assignment of firms to the second control group.

\subsubsection{Other concerns}

The first-time recognition of option expenses in earnings after FAS 123R could affect analysts' ability to forecast earnings. Specifically, analysts have to forecast a different type of earnings per share after FAS 123R, which could influence treatment firms' probability of meeting or beating analysts' forecasts. In this regard, prior research suggests that EPS consensus forecasts differ in whether they include or exclude stock option expenses (e.g., Entwistle et al. 2006; Barth et al. 2012) ${ }^{35}$ I use this differential

\footnotetext{
${ }^{35}$ Recall that I obtain both the EPS estimate and the actual EPS from I/B/E/S. Hence, option expenses are either included or excluded consistently in both the estimated EPS and the actual EPS.
} 
treatment to assess to what extent my results may be systematically biased by the change in accounting treatment. Following Barth et al. (2012), I use a Bear Stearns US Equity Research list to identify firms that have option-based compensation excluded from their consensus analysts' forecast in 2006 (excluders) (Senyek et al. 2007). These firms should not show any systematic effect. First, I test whether excluders show a change in beating analysts' forecasts around FAS 123R relative to firms with option expenses included in their consensus analysts' forecast (non-excluders). I do not find any differential changes for both groups. Similarly, I do not find a significant difference in the change in forecast errors. These tests indicate that including or excluding option expenses in the forecast does not systematically affect financial analysts' ability to forecast earnings. ${ }^{36}$ Next, I replicate all analyses based on the sample of non-excluders. $^{37}$ If the decline in beating analysts' forecasts in my main results was driven by analysts struggling to forecast earnings that include option expenses after FAS 123R, this effect should be particularly pronounced for non-excluders. However, based on the sample of non-excluders, I find very similar results in terms of magnitude and statistical significance (coefficient: -0.112 ; t-stat: -2.51). Relatedly, Entwistle et al. (2006) find that the portion of excluders remained approximately constant from 2001 to 2003. If FAS 123R had an effect on the inclusion or exclusion decision, one would expect to see a change, because several firms started early adoption during this period.

A related concern is that FAS $123 \mathrm{R}$ could have generally improved analysts' ability to forecast earnings because of more commonality in accounting methods. In this regard, Bradshaw et al. (2011) and DeFranco et al. (2011) suggest that analyst forecast errors are smaller when financial statements are more comparable across firms. Generally, greater commonality should affect financial analysts' information environment for both the treatment and control groups. However, to the extent that the treatment firms benefit differently from a potential increase in comparability, my results may be biased. I test this concern by analyzing forecast errors in the main difference-in-differences design. Untabulated results, however, show that forecast errors do not change differently for treatment firms compared with control firms. Hence, it is unlikely that an increase in commonality affects my results.

Next, given the controversy of FAS 123R, political economy concerns may be a threat to my identification. That is, firms may have lobbied against or in favor of FAS $123 \mathrm{R}$, and lobbying may be related to the outcome variable beating analysts' targets. If the lobbying activity is randomly spread among the treatment and control groups, it is not a concern. However, firms that voluntarily chose to expense options before FAS 123R or firms without options may have had incentives to lobby in favor of FAS 123R. If these incentives are also related to beating analysts' targets, the coefficients in my main tests may be biased. I address this concern in two ways. First, members of the high-technology sector have been particularly vocal critics of FAS 123R (Alsheimer 2006). Indeed, the majority of comment letters were written by employees of hightechnology firms. Hence, I verify that my results are similar when I remove hightechnology firms. ${ }^{38}$ Second, I examine all 6,536 comment letters to the exposure draft

\footnotetext{
$\overline{36}$ This result is not surprising because financial analysts are sophisticated users of financial statements (Schipper 1991), and they have had access to the option expense amount in the notes before FAS 123R. Hence, financial analysts' information set did not change with the introduction of FAS 123R.

${ }^{37}$ Alternatively, one could replicate the main analyses based on the subsample of excluders. Unfortunately, I cannot do this because only the treatment group contains excluders.

${ }^{38}$ To identify high-technology firms, I use the classification suggested by Kile and Phillips (2009).
} 
of FAS 123R and identify all sample firms whose employees submitted letters. I remove 204 firm-years of treatment firms and 11 firm-years of control firms. Based on this reduced sample, I replicate all analyses and find very similar results.

Another alternative explanation for my results is that the change in option pay may have encouraged some CEOs to leave their firms. Hence, treatment firms may experience more $\mathrm{CEO}$ fluctuation, which could drive the change in beating analysts' targets. In untabulated analyses, I show that CEO fluctuation does not increase for treatment firms compared with the control group. I also replicate all analyses while excluding firms that had a change in CEO. The results and inferences remain the same.

Furthermore, Bissessur and Veenman (2016) show that controlling for earnings forecast uncertainty can substantially alter the results in studies that use beating analysts' targets as an indicator of opportunistic management behavior. They argue that strategic analyst forecast pessimism is more likely to drive the results for beating analysts' targets in settings with high earnings forecast certainty. My results and inferences, however, do not change when I add a control for earnings forecast uncertainty (measured by the dispersion of analysts' forecasts used to build the consensus, as suggested by Bissessur and Veenman 2016).

Prior research suggests that earnings management and meeting or beating the analysts' earnings benchmark is particularly sensitive to CFO equity incentives (e.g., Jiang et al. 2010). Hence, I follow the approach of Jiang et al. (2010) to identify CFOs. Based on the CFO sample, I find a change in the compensation structure for CFOs that is similar to the change reported for CEOs in Table 3. I also replicate the main test based on the CFO sample. This approach does not change my inferences.

For some firms in the sample, earnings may not be the relevant benchmark that investors ultimately care about. In terms of equity valuation, Trueman et al. (2001) suggest that forecasting revenues, although challenging (e.g., Curtis et al. 2014), is particularly important for high-technology firms with growth potential. At the same time, growth firms in the high-technology sector use option compensation to a large extent. Generally, this issue should work against my findings because the treatment group, which includes relatively more high-technology firms than the control group, should be affected less if earnings are an irrelevant benchmark for it. However, I use the potential focus on a different benchmark to further corroborate my main findings. Specifically, I focus on high-technology firms (as defined before) and restrict my sample to high-technology firms that have more forecasts of individual analysts included in the consensus sales forecast than in the consensus earnings forecasts. ${ }^{39}$ For these firms, sales is likely to be a more important performance indicator. I rerun my main tests and classify, as meet or beat firms, any firms that marginally beat sales forecasts by up to $1 \%$ of the mean of actual sales and forecasted sales. I again find a strong decline in meeting or just beating analysts' consensus sales forecasts. While the statistical significance is slightly lower ( $p$ value: 0.077 ) because of the reduced sample size (n: 906), the coefficient estimate of the interaction term is even greater $(-0.250$ compared to -0.109 for the OLS specification with firm and year fixed effects). Note, however, that I do not find a significant change in meeting or just beating analysts' sales forecasts based on the entire sample.

\footnotetext{
${ }^{39}$ To retain a testable number of observations, it is sufficient if firms have at least one year with more sales than earnings forecasts during my sample period.
} 
Finally, similar to Feng and McVay (2010) and Quinn (2018), I determine which magnitude of any remaining hidden correlated omitted variables bias would be required to overturn my results. Specifically, following Frank (2000) and Feng et al. (2009), I measure the impact threshold for an omitted variable. This threshold indicates how closely an omitted variable would have to be correlated with both the dependent variable (Meet or beat) and the interaction term (Post * Treat) to render the results insignificant. Conditioned on the observed control variables, an omitted variable would have to be correlated at 0.095 with Meet or beat and at -0.095 with the interaction term to invalidate my inferences. This result means the impact of any potentially omitted variable would have to be 2.6 times greater than the strongest control in my main specification, which makes it unlikely that an omitted variable would overturn the results.

In summary, these sensitivity checks provide evidence that I can draw plausible causal inferences regarding the effect of option pay on opportunistic management behavior in my setting. Two important caveats, however, apply. First, the introduction of FAS 123R coincides with the widespread prevalence of earnings management. Hence, the results may not generalize to settings in which earnings management is already on a normal or low level. Second, my results are based on relatively high levels of option pay before FAS 123R. Consequently, the findings may not extend to today's compensation practices, which include significantly lower levels of option pay (e.g., Roe and Papadopoulos 2019).

\subsection{Further corroborating evidence}

\subsubsection{What channels do managers use to meet or beat targets?}

In this section, to corroborate my main findings, I shed further light on manager behavior around the change in beating analysts' forecasts. Specifically, I show what channels managers use to meet or beat targets (i.e., accrual management, real activities manipulation, or analyst manipulation). To maximize the power of the tests, I focus on firms in my treatment group that show a decrease in meeting or beating analysts' forecasts from the pre-FAS $123 \mathrm{R}$ period to the post-FAS $123 \mathrm{R}$ period. $^{40}$

Identifying the channels underlying this decrease in beating analysts' targets allows a deeper understanding of managers' motives and behavior. Prior research has identified four tools that managers may use to meet or beat analysts' targets: (1) "within GAAP" accrual management (e.g., Abarbanell and Lehavy 2003; Burgstahler and Eames 2006; McVay et al. 2006), (2) real activities manipulation (e.g., Roychowdhury 2006; Gunny 2010), (3) analyst expectations management (e.g., Kasznik and Lev 1995; Matsumoto 2002; Doyle et al. 2013), and (4) "outside of GAAP" manipulations (e.g., Chu et al. 2019). These tools reflect a wide variety of accounting actions and real actions. If the relatively high levels of target beating for the treatment firms before FAS 123R are achieved using these

\footnotetext{
${ }^{40}$ I propensity score match these firms with my control group using all control variables of my main model allowing a maximum caliper range of 0.01 . Moreover, I use one-to-one matching without replacement over the common support region, and I ensure covariate balance (see Table A.10). Because of these demanding matching requirements, the matched sample comprises only 42 treatment firms of the overall 263 treatment firms that show a decline in meeting or beating analysts' forecasts. Moreover, note that the results become substantially weaker when using the full sample without matching; this is not surprising, given that each of the channels represents just one of many options to meet or beat analysts' forecasts. Hence, by focusing on firms that actually show a decrease in beating analysts' targets, I have more power to detect any effects.
} 
opportunistic tools, I should observe a decline in the use of at least one of the tools. I measure "within GAAP" accrual management with performance-adjusted discretionary accruals (Kothari et al. 2005). To proxy for real activities manipulation, I follow Gunny (2010) and use discretionary sales of fixed assets to report gains; cutting prices to boost sales; and discretionary cuts in R\&D and SG\&A to decrease expenses. To measure analyst expectations management, I use two approaches. First, similar to Bartov et al. (2002), I determine the difference between the first EPS forecast of the fiscal year and the last forecast before the end of that year, scaled by actual EPS. Negative values imply a forecast walk-down over the fiscal period, which is consistent with expectation-reducing guidance. Second, following Doyle et al. (2013), I measure whether, to beat analyst targets, firms opportunistically define non-GAAP earnings in a way that analysts fail to fully anticipate. An observation is defined as a positive exclusion firm when the IBES-reported actual EPS exceeds the GAAP EPS. ${ }^{41}$ Finally, to capture "outside of GAAP" manipulations, I also consider whether the probability of restatements changes. I obtain restatements from Audit Analytics. ${ }^{42}$

Table 7 reports the results. I run firm and year fixed effects OLS regressions with the same controls as before and standard errors clustered at the firm level. Column 1 shows that there is no significant change in accrual management. Columns 2-5 report the results for real activities manipulation. Firms with a decrease in meeting or beating analysts' targets show a significant decline in discretionary asset sales (Column 2) and fewer discretionary sales manipulations (Column 3). ${ }^{43}$ However, I cannot find a change in the treatment firms' forecast walk-downs (Column 6), probability of opportunistically defining non-GAAP earnings (Column 7), or restatements (Column 8). Hence, my sample firms have primarily used real activities manipulation to meet or beat analysts' forecasts. This result is consistent with Dechow et al. (2003) and Bauman et al. (2005), who find no evidence that accrual manipulation is behind the discontinuity in earnings distributions. ${ }^{44}$

\subsubsection{Field evidence}

Finally, I complement the archival findings with an exploratory field study via semistructured interviews with six CEOs. More importantly, I interview CEOs that are part of my sample, which allows me to interpret the findings in the same light as the archival results of the study. Most of the CEOs were retired by the time of the interviews, which made contact easier. ${ }^{45}$ The main objectives of the interviews were to (1) assess how

\footnotetext{
${ }^{41}$ I define GAAP EPS as the Compustat item "earnings per share before extraordinary items and discontinued operations" using either diluted or basic EPS, depending on the IBES classification. For a detailed description of the measure, see Doyle et al. (2013).

${ }^{42}$ Note that the sample size changes for these regressions because of the matching procedure and data availability for the dependent variable.

43 This finding is consistent with Dechow and Schrand (2004), who report that overstating revenues is the most common type of earnings management (more than 70\%) of AAER firms.

${ }^{44}$ Note that this result is in contrast with McVay et al. (2006), who find discretionary working capital accruals to be the main mechanism to meet or beat analysts' targets. However, McVay et al. (2006) consider a specific subset of firms whose managers sell their shares after beating the analysts' forecasts.

${ }^{45}$ From a random sample of 200 CEOs in my sample in 2004, I managed to get some form of contact information (address, telephone, email address, website, LinkedIn) for 26 via an online search. I contacted the majority of CEOs on LinkedIn and via email. Six of eight respondents agreed to take part in the interview. The interviews were conducted in fall/winter 2017 via telephone. All interviews were recorded and transcribed, and interviewees were promised anonymity.
} 


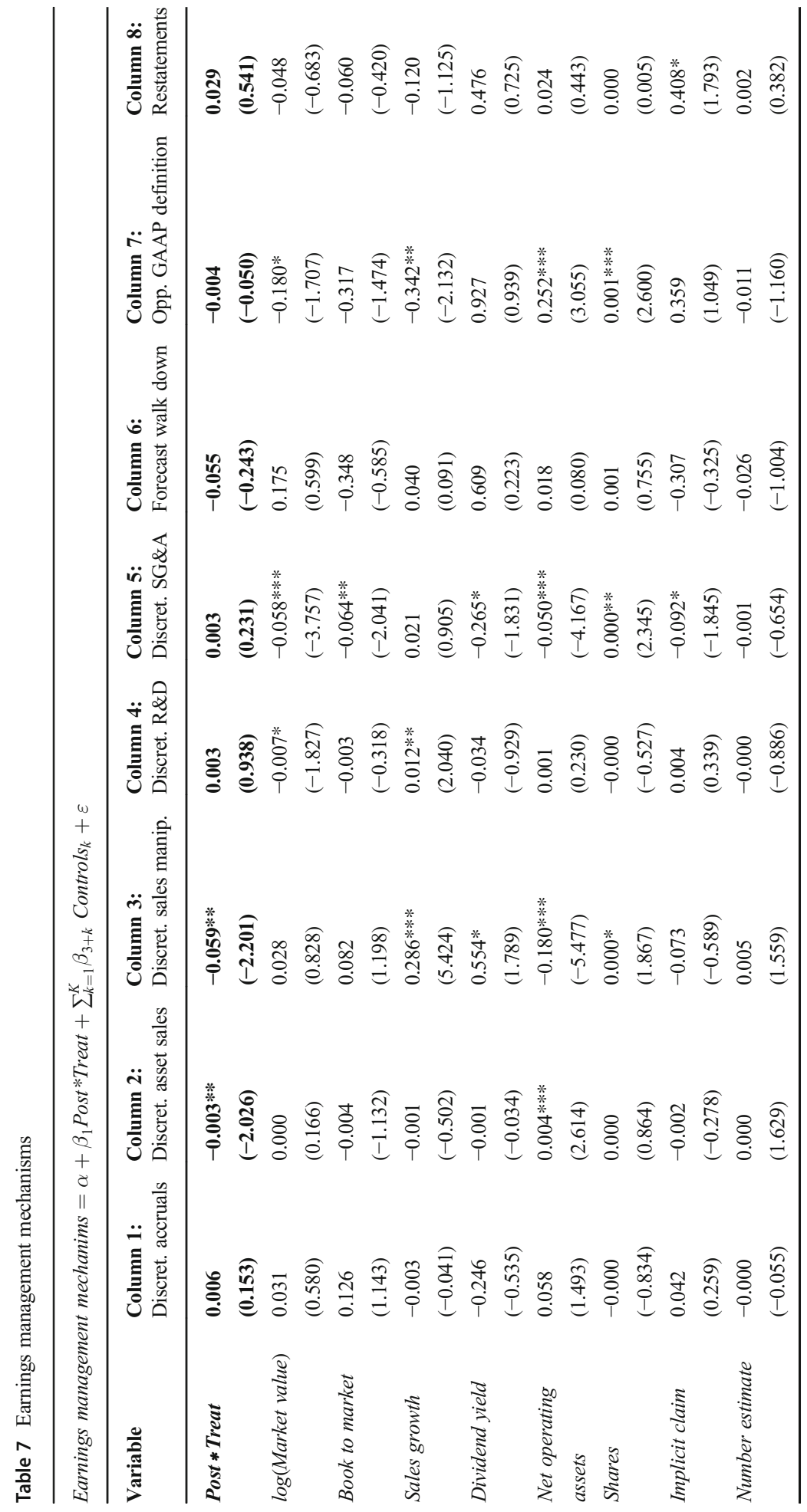




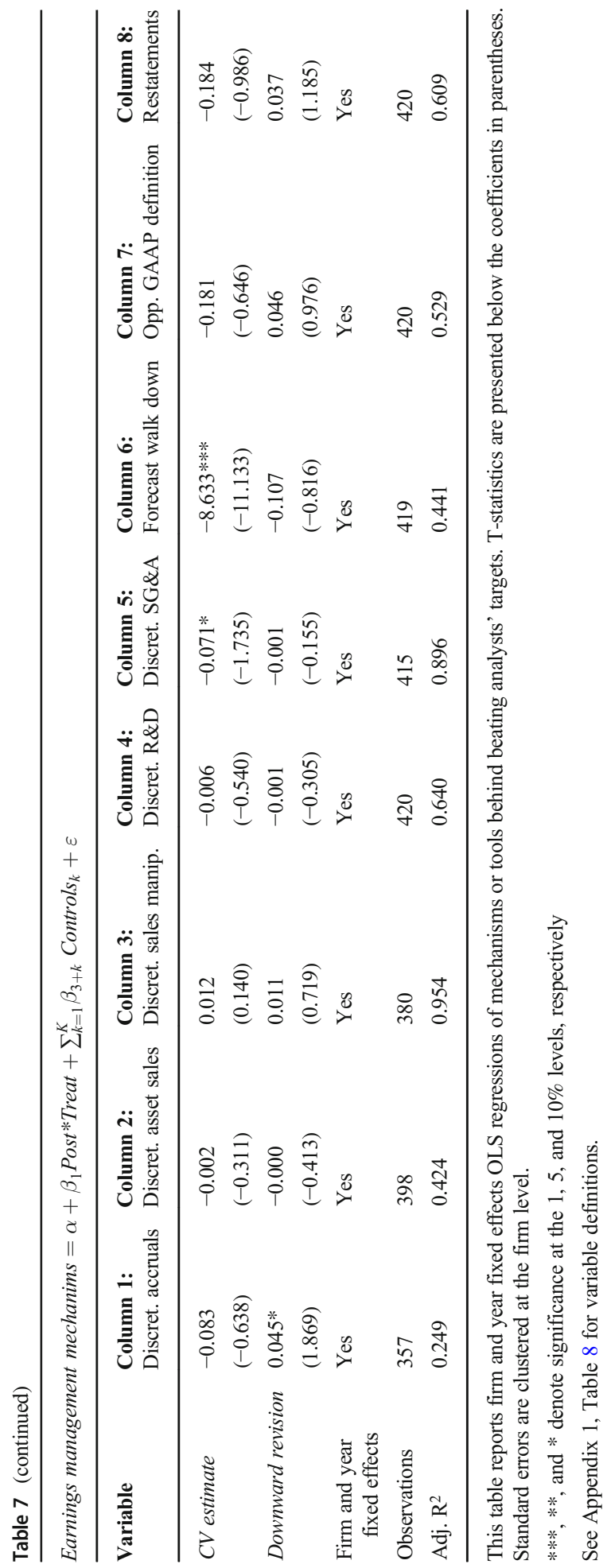


CEOs at that time perceived meeting or beating analysts' forecasts, (2) shed light on how CEOs perceived the incentive effects of option pay, and (3) find out what channels CEOs use to meet or beat targets.

When asked about the importance of meeting or beating analysts' targets, one CEO noted, "I think it is extremely important but I would add the word unfortunately to that. I think the analysts and the stock market and its practices really stimulate short-term thinking, which is ultimately not in the best interest of the stockholders." Another CEO said, "That's what you're off to do: to meet or at least beat the financial forecast. The consequence of not doing that is rather painful." One CEO referred to compensation in this context even though s/he had not been asked about it, saying, "[Meeting or beating forecasts] is very important - extremely important. And so the more you tie that to compensation, then [CEOs] are more likely_-depending upon if they have a propensity to be dishonest - they will do just that, they will do dishonest things."

Whether option pay instills opportunistic behavior is a sensitive topic for CEOs, ${ }^{46}$ but several noted the potential negative effects of option pay in this regard. One observed that "especially on CEO levels, incentive compensation can cause behavior that is not in the long term interest of the company because in that sense it separates the individual's future from that of the company." Another noted, "It creates stress, which influences decisionmaking." One interviewee mentioned the issues that go along with the short-term nature of the job and option pay: "CEO as a position is a job for six to eight, maybe ten years. So it is not long-term. If one is incentivized to maximize one's income, well, [...] I am not saying that all people are out-for-sale [...] but one's behavior will be influenced to maximize that." Excessive option pay in particular was criticized. One CEO said, "To be positive, [options] have to be granted in appropriate places and appropriate quantities and with appropriate expectations." Another notion that emerged during the interviews was that founder CEOs are systematically different in this regard, as "compensation is basically a side effect" for them. This notion is consistent with the data, because the treatment effect disappears when I rerun the main test based on founder CEOs. ${ }^{47}$

The CEOs mentioned several means by which meeting or beating analysts' targets was done in practice. For example, CEOs referred to the notion of real activities manipulation several times. One said, "You would never do anything illegal. That is really not just bad practice - that is stupid. [...] But there are things - I mean if you have a big order from a customer and he wants it on February $2^{\text {nd }}$, you're going to try to get permission if your fiscal quarter ends in January whether you can deliver a product a week earlier. And that might add one penny to your earnings." Other options are "a sales contest, which will boost your sales, but it is going to come out of next month's sales" and to "give customers discounts to take products ahead [of time]." One CEO noted that s/he later used her/his experience when assuming supervisory board responsibilities to prevent real activities manipulation: "I was chairman of the audit committee of a large [*industry mentioned] company and [...] we guarded against people moving invoices forward or back in order to meet quarterly earnings targets. And there were severe penalties for people who did." The notion of sales manipulation is also

\footnotetext{
$\overline{46}$ To accommodate the sensitive nature of the topic, I chose to pose questions in an indirect, nonconfrontational way. For example, instead of asking whether they were personally incentivized to act opportunistically by their option compensation, I asked that question in reference to CEOs in general.

${ }^{47}$ I thank Rüdiger Fahlenbrach for sharing his founder CEO data; see Fahlenbrach (2009) for details.
} 
consistent with the results in Table 7 , which show discretionary sales manipulation to be one of the main drivers of meeting or beating analysts' targets.

Accounting discretion is another channel that the interviewees mentioned. One CEO noted that one "can defer recognition of gains in different areas or defer losses, recognizable losses. You know, accounting is not a totally exact science." Another noted, "There are things that are manageable and things that are not. So one can play with that which is manageable. One could play with current receivables and current liabilities, one can play with inventories." The same CEO, however, noted that accrual management became much less relevant over time: "There is much less of that now. The accounting rules are pretty strict." Another CEO supported this notion, saying, "There is so much scrutiny over the financials that it is hard to cheat on the financials themselves." Similarly, another CEO remarked that discretion regarding accounting is limited: "You really cannot change the balance sheet, right? You can only really play with the numbers by physically doing something like shipping ahead [...]. Vendors do that all the time."

Overall, the interviews support that several means exist, and that real activities manipulations are the key mechanism. The extent, however, to which one can manipulate earnings has boundaries. "Can you make a dramatic difference?" asked one CEO. "I would say the answer is no. Can you make a small difference, you know, from a dollar-sixteen to a dollar-eighteen? I would say probably."

Although the interview evidence does not generalize and can only be considered exploratory, it bolsters confidence in the main results by showing that (1) the dependent variable Meet or beat is a relevant measure during the sample period; (2) CEOs confirm the potential negative incentives created by option pay, which I use to explain the findings; and (3) real activities manipulations - discretionary sales manipulations in particular-are the main tools to achieve earnings targets.

\section{Conclusion}

In this study, I exploit the quasi-natural experiment created by the introduction of FAS 123R with a difference-in-differences research design to reexamine the hitherto unresolved question of whether option pay leads to opportunistic management behavior. The introduction of FAS $123 \mathrm{R}$ led to a more than $35 \%$ decline in option pay of CEOs from firms affected by the regulation. I find that this decline in option pay caused a significant decrease of $14-20 \%$ in the likelihood of a firm meeting or beating its analysts' forecasts. This finding is robust to a battery of sensitivity checks, suggesting that option pay encourages opportunistic management behavior.

I contribute to the management compensation literature by establishing a plausible causal link between option pay and opportunistic manager behavior - a question to which prior theoretical and empirical evidence provided conflicting answers. Moreover, the finding that the meet-or-beat phenomenon is largely driven by real activities manipulation adds to the literature on discontinuities in earnings distributions.

Supplementary Information The online version contains supplementary material available at https://doi.org/ 10.1007/s11142-021-09633-5. 
Acknowledgements I thank Patricia M. Dechow (editor), Wayne Guay, Peter Kajüter, Florian Klassmann, Alastair Lawrence, Max Meinhövel, Alexander Merz, Maximilian Muhn, Phillip Quinn, Harm Schütt, Anna Rohlfing-Bastian, Simon Rottke, Stephen A. Zeff, two anonymous reviewers, participants at the EAA 2017 congress, and workshop participants at Rice University, Technical University of Dortmund, and the University of Tübingen for their helpful comments and suggestions. All remaining errors are mine.

Funding Open Access funding enabled and organized by Projekt DEAL.

\section{Appendix}

Table 8 Variable definitions

\begin{tabular}{|c|c|c|}
\hline Variable & Unit & Definition \\
\hline Altman $-Z_{i, t}$ & ratio & $\begin{array}{l}\text { Calculated as } \mathrm{Z}=1.2 *((\text { current assets }- \text { current liabilities }) / \text { total assets })+ \\
1.4 *(\text { retained earnings/total assets })+3.3 *(\text { earnings before } \\
\text { interest/total assets })+0.6 * \text { (market value of equity/book value of total } \\
\text { debt })+0.999 *(\text { sales } / \text { total assets }) \text { for firm } i \text { in fiscal year } t .\end{array}$ \\
\hline Bonus $_{i ; t}$ & \$ million & CEO bonus payment of firm $i$ in fiscal year $t$. \\
\hline 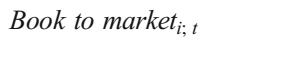 & ratio & $\begin{array}{l}\text { Book value of equity divided by market value of equity of firm } i \text { in fiscal } \\
\text { year } t \text {. }\end{array}$ \\
\hline $\operatorname{Cash}_{i, t}$ & ratio & Cash and cash equivalents divided by total assets of firm $i$ in fiscal year $t$. \\
\hline CEO tenure $_{i, t}$ & years & Number of years as CEO for firm $i$ in fiscal year $t$. \\
\hline CEO turnover $_{i ; t}$ & dummy & 1 if firm $i$ had a change in CEOs in fiscal year $t$. \\
\hline CV estimate $_{i ; t}$ & ratio & $\begin{array}{l}\text { Coefficient of variation of the forecasts included in the consensus } \\
\text { forecast for firm } i \text { in fiscal year } t\end{array}$ \\
\hline Delta $_{i ; t}$ & & $\begin{array}{l}\text { (Black-Scholes Delta of all current option grants }+ \text { number of shares of } \\
\text { current restricted stock grants }+ \text { number of targeted shares granted } \\
\text { under LTIA) } * \text { (fiscal year-end price } * 0.01) \text {. }\end{array}$ \\
\hline Dividends $_{i ; t}$ & dummy & 1 if firm $i$ paid cash dividends in fiscal year $t$. \\
\hline 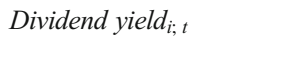 & ratio & $\begin{array}{l}\text { Paid cash dividends divided by market value of equity of firm } i \text { in fiscal } \\
\text { year } t \text {. }\end{array}$ \\
\hline 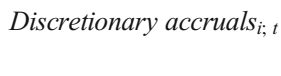 & & $\begin{array}{l}\text { Calculated as deviations from the predicted values based on the } \\
\text { performance-matched procedures following Kothari et al. (2005). }\end{array}$ \\
\hline $\begin{array}{l}\text { Discretionary asset } \\
\text { sales }_{i ; t}\end{array}$ & & $\begin{array}{l}\text { Calculated as deviations from the predicted values based on an } \\
\text { industry-year regression following Gunny (2010). }\end{array}$ \\
\hline Discretionary $R \& D_{i ; t}$ & & $\begin{array}{l}\text { Calculated as deviations from the predicted values based on an } \\
\text { industry-year regression following Gunny (2010). }\end{array}$ \\
\hline $\begin{array}{l}\text { Discretionary sales } \\
\quad \text { manipulations } s_{i ; t}\end{array}$ & & $\begin{array}{l}\text { Calculated as deviations from the predicted values based on an } \\
\text { industry-year regression following Gunny (2010). }\end{array}$ \\
\hline Discretionary $S G \& A_{i ; t}$ & & $\begin{array}{l}\text { Calculated as deviations from the predicted values based on an } \\
\text { industry-year regression following Gunny (2010). }\end{array}$ \\
\hline Downward revision $_{i ; t}$ & dummy & $\begin{array}{l}1 \text { if one or more of the firm's analysts revised her forecast downwards in } \\
\text { the last forecast before the earnings announcement for firm } i \text { in fiscal } \\
\text { year } t \text {. }\end{array}$ \\
\hline Earnings volatility $_{i ; t}$ & & Standard deviation of quarterly net income for firm $i$ in fiscal year $t$. \\
\hline Forecast error $_{i, t}$ & & $\begin{array}{l}\text { Difference between the actual earnings per share (taken from } \mathrm{I} / \mathrm{B} / \mathrm{E} / \mathrm{S} \text { ) } \\
\text { and the last analysts' forecast of earnings per share for firm } i \text { in fiscal } \\
\text { year } t \text {. }\end{array}$ \\
\hline
\end{tabular}


Table 8 (continued)

\begin{tabular}{|c|c|c|}
\hline Variable & Unit & Definition \\
\hline Forecast walk down $n_{i, t}$ & & $\begin{array}{l}\text { Difference between the first EPS forecast of the fiscal year and the last } \\
\text { forecast before right before the end of that year scaled by actual EPS } \\
\text { of firm } i \text { in fiscal year } t \text {. }\end{array}$ \\
\hline 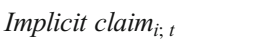 & ratio & 1 minus the ratio of gross PPE to total assets of firm $i$ in fiscal year $t$. \\
\hline Investment growth $h_{i ; t}$ & ratio & $\begin{array}{l}\text { Percentage change in capital expenditures from fiscal year } t-1 \text { to fiscal } \\
\text { year } t \text { for firm } i \text {. }\end{array}$ \\
\hline Leverage $_{i ; t}$ & ratio & Long-term debt divided by total assets of firm $i$ in fiscal year $t$. \\
\hline 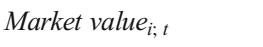 & \$ million & Market value of equity of firm $i$ at the end of fiscal year $t$. \\
\hline Meet or beat ${ }_{i ; t}$ & dummy & $\begin{array}{l}1 \text { if firm } i \text { just meets or beats the last analysts' consensus forecast of } \\
\text { earnings per share by not more than } \$ 0.01 \text { (i.e., earnings surprise per } \\
\text { share within [ } \$ 0 ; \$ 0.01] \text { ), and zero otherwise in fiscal year } t \text {. }\end{array}$ \\
\hline Meet or beat sales ${ }_{i, t}$ & dummy & $\begin{array}{l}1 \text { if firm } i \text { just meets or beats the last analysts' consensus forecast of sales } \\
\text { by up to } 1 \% \text { of the mean of actual sales and forecasted sales, and zero } \\
\text { otherwise in fiscal year } t \text {. }\end{array}$ \\
\hline Net operating assets $_{i ; t}$ & \$ million & $\begin{array}{l}\text { Shareholders' equity minus cash and marketable securities plus total debt } \\
\text { of firm } i \text { in fiscal year } t \text {. }\end{array}$ \\
\hline Number estimate $_{i ; t}$ & integer & $\begin{array}{l}\text { Number of financial analysts whose forecasts are included in the } \\
\text { consensus forecast for firm } i \text { in fiscal year } t \text {. }\end{array}$ \\
\hline $\begin{array}{l}\text { Opportunistic GAAP }^{\text {definition }}, ;, t\end{array}$ & dummy & $\begin{array}{l}1 \text { if IBES Actual EPS is higher than the per share GAAP earnings } \\
\text { number for firm } i \text { in fiscal year } t \text {. GAAP EPS is measured as earnings } \\
\text { per share before extraordinary items and discontinued operations } \\
\text { (either basic or diluted depending on the IBES flag). }\end{array}$ \\
\hline Option pay ratio $i ; t$ & ratio & $\begin{array}{l}\text { Ratio of CEO stock option compensation to total CEO compensation of } \\
\quad \text { firm } i \text { in fiscal year } t \text {. }\end{array}$ \\
\hline $\mathrm{POST}_{t}$ & dummy & $\begin{array}{l}\text { Indicator variable that is one after the introduction of FAS } 123 \mathrm{R} \text {, and } \\
\text { zero otherwise. }\end{array}$ \\
\hline Restatement $_{i ; t}$ & dummy & $\begin{array}{l}1 \text { if of firm } i \text { had a restatement related to the financial statements of fiscal } \\
\text { year } t \text {. }\end{array}$ \\
\hline $\begin{array}{l}\text { Return on } \text { assets }_{i ; t} / \\
\qquad \text { ROA }_{i ; t}\end{array}$ & ratio & $\begin{array}{l}\text { Earnings before interest and taxes divided by total assets of fiscal year } t-1 \\
\text { of firm } i \text {. }\end{array}$ \\
\hline Return volatility $_{i, t}$ & & Annual standard deviation of daily returns for firm $i$ in fiscal year $t$. \\
\hline Sales growth ${ }_{i, t}$ & ratio & Sales of fiscal year $t$ divided by sales of fiscal year $t-1$ of firm $i$. \\
\hline Shares $_{i ; t}$ & million & $\begin{array}{l}\text { Number of common shares outstanding at the end of fiscal year } t \text { of firm } \\
i \text {. }\end{array}$ \\
\hline Total assets $_{i ; t}$ & \$ million & Total assets of firm $i$ in fiscal year $t$ \\
\hline Total compensation $_{i ; t}$ & \$ million & Total CEO compensation of firm $i$ in fiscal year $t$. \\
\hline$T R E A T_{i}$ & dummy & $\begin{array}{l}\text { Indicator variable that is one if the firm is part of the treatment group, } \\
\text { and zero otherwise. }\end{array}$ \\
\hline $\operatorname{Veg} a_{i ; t}$ & & Black-Scholes Vega of all current option grants $* 0.01$ \\
\hline
\end{tabular}


Open Access This article is licensed under a Creative Commons Attribution 4.0 International License, which permits use, sharing, adaptation, distribution and reproduction in any medium or format, as long as you give appropriate credit to the original author(s) and the source, provide a link to the Creative Commons licence, and indicate if changes were made. The images or other third party material in this article are included in the article's Creative Commons licence, unless indicated otherwise in a credit line to the material. If material is not included in the article's Creative Commons licence and your intended use is not permitted by statutory regulation or exceeds the permitted use, you will need to obtain permission directly from the copyright holder. To view a copy of this licence, visit http:// creativecommons.org/licenses/by/4.0/.

\section{References}

Abarbanell, Jeffery, and Reuven Lehavy. (2003). Biased forecasts or biased earnings? The role of reported earnings in explaining apparent bias and over/underreaction in analysts' earnings forecasts. Journal of Accounting and Economics 36 (1-3): 105-146. https://doi.org/10.1016/j.jacceco.2003.11.001.

Ahmed, A.S., E. Kilic, and G.J. Lobo. (2006). Does recognition versus disclosure matter? Evidence from value-relevance of banks' recognized and disclosed derivative financial instruments. The Accounting Review 81 (3): 567-588.

Ai, C., and E.C. Norton. (2003). Interaction terms in logit and probit models. Economics Letters 80 (1): 123129.

Allen, E.J., P.M. Dechow, D.G. Pope, and G. Wu. (2017). Reference-dependent preferences: Evidence from marathon runners. Management Science 63 (6): 1657-1672.

Alsheimer, A. (2006). Assessing corporate America's opposition to the FASB's new stock options expensing policy. Entrepreneurial Business Law Journal 1 (1): 43-61.

Angrist, J.D., and J.-S. Pischke. (2008). Mostly harmless econometrics: An empiricist's companion. Princeton Univers. Press.

Armstrong, C.S., A.D. Jagolinzer, and D.F. Larcker. (2010). Chief executive officer equity incentives and accounting irregularities. Journal of Accounting Research 48 (2): 225-271.

Armstrong, C.S., and R. Vashishtha. (2012). Executive stock options, differential risk-taking incentives, and firm value. Journal of Financial Economics 104 (1): 70-88.

Armstrong, C.S., D.F. Larcker, G. Ormazabal, and D.J. Taylor. (2013). The relation between equity incentives and misreporting: The role of risk-taking incentives. Journal of Financial Economics 109 (2): 327-350.

Ayers, B., J. Jiang, and E. Yeung. (2006). Discretionary accruals and earnings management: An analysis of pseudo earnings targets. The Accounting Review 81 (3): 617-652.

Baker, T., D. Collins, and A. Reitenga. (2003). Stock option compensation and earnings management incentives. Journal of Accounting, Auditing \& Finance 18 (4): 557-582.

Bakke, T.E., H. Mahmudi, C.S. Fernando, and J.M. Salas. (2016). The causal effect of option pay on corporate risk management. Journal of Financial Economics 120 (3): 623-643.

Ball, R., and P. Brown. (1968). An empirical evaluation of accounting income numbers. Journal of Accounting Research 6 (2): 159-178.

Barth, M.E., G. Clinch, and T. Shibano. (2003). Market effects of recognition and disclosure. Journal of Accounting Research 41 (4): 581-609.

Barth, M.E., I.D. Gow, and D.J. Taylor. (2012). Why do pro forma and street earnings not reflect changes in GAAP? Evidence from SFAS 123R. Review of Accounting Studies 17 (3): 526-562.

Bartov, E., D. Givoly, and C. Hayn. (2002). The rewards to meeting or beating earnings expectations. Journal of Accounting and Economics 33 (2): 173-204.

Bartov, E., and P. Mohanram. (2004). Private information, earning manipulations, and executive stock-option exercises. The Accounting Review 79 (4): 889-920.

Bauman, M.P., M. Braswell, and K.W. Shaw. (2005). The numbers game: How do managers compensated with stock options meet analysts' earnings forecasts? Research in Accounting Regulation 18 (1): 3-28.

Baumann, M.P., and K.W. Shaw. (2006). Stock option compensation and the likelihood of meeting analysts' quarterly earnings targets. Review of Quantitative Finance and Accounting 26 (3): 301-319.

Beaver, W., M. McNichols, and K. Nelson. (2007). An alternative interpretation of the discontinuity in earnings distributions. Review of Accounting Studies 12 (4): 525-556.

Bergstresser, D., and T. Philippon. (2006). CEO incentives and earnings management. Journal of Financial Economics 80 (3): 511-529. 
Bettis, J., J. Coles, and M. Lemmon. (2000). Corporate policies restricting trading by insiders. Journal of Financial Economics 57 (2): 191-220.

Bissessur, S.W., and D. Veenman. (2016). Analyst information precision and small earnings surprises. Review of Accounting Studies 21 (4): 1327-1360.

Bradshaw, M., G. Miller, Serafeim, G. (2011). Accounting method heterogeneity and analysts' forecast errors, Working Paper.

Brown, K. (2002). Questioning the books: Tweaking results is hardly a sometime thing - many firms, under diverse pressures, may play with numbers. Wall Street Journal, February 6, C1.

Brown, L.D., and Y.-J. Lee. (2011). Changes in option-based compensation around the issuance of SFAS 123R. Journal of Business Finance \& Accounting 38 (9): 1053-1095.

Burgstahler, D.C., and I. Dichev. (1997). Earnings management to avoid earnings decreases and losses. Journal of Accounting and Economics 24 (1): 99-126.

Burgstahler, D.C., and M.J. Eames. (2003). Earnings management to avoid losses and earnings decreases: Are analysts fooled? Contemporary Accounting Research 20 (2): 253-294.

Burgstahler, D.C., and M.J. Eames. (2006). Management of earnings and analysts' forecasts to achieve zero and small positive earnings surprise. Journal of Business Finance and Accounting 33 (5-6): 633-652.

Burns, N., and S. Kedia. (2006). The impact of performance-based compensation on misreporting. Journal of Financial Economics 79 (1): 35-67.

Carter, M.E., L.J. Lynch, and S.L.C. Zechman. (2009). Changes in bonus contracts in the post-Sarbanes-Oxley era. Review of Accounting Studies 14 (4): 480-506.

Cheng, Q., and T.D. Warfield. (2005). Equity incentives and earnings management. The Accounting Review 80 (2): 441-476.

Chu, J., P.M. Dechow, K.W. Hui, and A.Y. Wang. 2019. Maintaining a reputation for consistently beating earnings expectations and the slippery slope to earnings manipulation. Contemporary Accounting Research 36 : 1966-1998. https://doi.org/10.1111/1911-3846.12492.

Cohen, D.A., A. Dey, and T.Z. Lys. (2008). Real and accrual-based earnings management in the pre- and postsarbanes-oxley periods. The Accounting Review 83 (3): 757-787.

Coles, J.L., N.D. Daniel, and L. Naveen. (2006). Managerial incentives and risk-taking. Journal of Financial Economics 79 (2): 431-468.

Curtis, A.B., R.J. Lundholm, and S.E. McVay. (2014). Forecasting sales: A model and some evidence from the retail industry. Contemporary Accounting Research 31 (2): 581-608.

Dechow, P. M., A. P. Hutton, and R. G. Sloan. (1996a). Economic consequences of accounting for stockbased compensation. Journal of accounting research 34 (studies on recognition, measurement, and disclosure issues in accounting): 1-20.

Dechow, P.M., R.G. Sloan, and A.P. Sweeney. (1996b). Causes and consequences of earnings manipulation: An analysis of firms subject to enforcement actions by the SEC. Contemporary Accounting Research 13 (1): $1-36$.

Dechow, P.M., S. Richardson, and I. Tuna. (2003). Why are earnings kinky? An examination of the earnings management explanation. Review of Accounting Studies 8 (2): 355-384.

Dechow, P. M., and C. Schrand. (2004). Earnings quality. The Research Foundation of CFA Institute. Charlottesville, Virginia.

DeFranco, G., S.P. Kothari, and R. Verdi. (2011). The benefits of financial statement comparability. Journal of Accounting Research 49 (4): 895-931.

Degeorge, F., J. Patel, and R. Zeckhauser. (1999). Earnings management to exceed thresholds. Journal of Business 72 (1): 1-35.

Denis, D.J., P. Hanouna, and A. Sarin. (2006). Is there a dark side to incentive compensation? Journal of Corporate Finance 12 (3): 467-488.

Dhaliwal, D., C. Gleason, and L. Mills. (2004). Last chance earnings management: Using the tax expense to achieve earnings targets. Contemporary Accounting Research 21 (2): 430-459.

Doyle, Jeffrey T., Jared N. Jennings, and Mark T. Soliman. 2013. Do managers define non-GAAP earnings to meet or beat analyst forecasts? Journal of Accounting and Economics 56 (1): 40-56. https://doi.org/10. 1016/j.jacceco.2013.03.002.

Durtschi, C., and P. Easton. (2005). Earnings management? The shapes of the frequency distributions of earnings metrics are not evidence ipso facto. Journal of Accounting Research 43 (4): 557-592.

Durtschi, C., and P. Easton. (2009). Earnings management? Erroneous inferences based on earnings frequency distributions. Journal of Accounting Research 47 (5): 1249-1281.

Edmans, A., V.W. Fang, and K.A. Lewellen. (2017). Equity vesting and investment. Review of Financial Studies 30 (7): 2229-2271. 
Edmans, A., and X. Gabaix. (2015). Executive compensation: A modern primer. Working paper 21131, National Bureau of economic research. Available at: http://www.nber.org/papers/ w21131.

Efendi, J., A. Srivastava, and E.P. Swanson. (2007). Why do corporate managers misstate financial statements? The role of option compensation and other factors. Journal of Financial Economics 85 (3): 667708.

Entwistle, G.M., G.D. Feltham, and C. Mbagwu. (2006). Financial reporting regulation and the reporting of pro forma earnings. Accounting Horizons 20 (1): 39-55.

Erickson, M., M. Hanlon, and E.L. Maydew. (2006). Is there a link between executive equity incentives and accounting fraud? Journal of Accounting Research 44 (1): 113-143.

Ertimur, Y., F. Ferri, and D.A. Maber. (2012). Reputation penalties for poor monitoring of executive pay: Evidence from option backdating. Journal of Financial Economics 104 (1): 118-144.

Fama, E.F. (1980). Agency problems and the theory of the firm. The Journal of Political Economy 88 (2): 288-307.

Feroz, E. H., K. Park, and V. S. Pastena. (1991). The financial and market effects of the SEC's accounting and auditing enforcement releases. Journal of accounting research 20 (Suppl.): 107-142.

Feng, M., C. Li, and S. McVay. (2009). Internal control and management guidance. Journal of Accounting and Economics 48 (2): 190-209.

Feng, M., W. Ge, S. Luo, and T. Shevlin. (2011). Why do CFOs become involved in material accounting manipulations? Journal of Accounting and Economics 51 (1): 21-36.

Feng, M., and S. McVay. (2010). Analysts' incentives to overweight management guidance when revising their short-term earnings forecasts. The Accounting Review 85 (5): 1617-1646.

Ferri, F., and N. Li. (2018). Does option-based compensation affect payout policy? Evidence from FAS123R. Journal of Financial and Quantitative Analysis forthcoming.

Frank, K. (2000). Impact of a confounding variable on a regression coefficient. Sociological Methods \& Research 29 (2): 147-194.

Frydman, C., and D. Jenter. (2010). CEO compensation. Annual Review of Financial Economics 2 (1): 75102.

Gao, P., and R. E. Shrieves. (2002). Earnings management and executive compensation: A case of overdose of option and underdose of salary? Workings Paper, University of Tennessee.

Graham, J.R., C.R. Harvey, and S. Rajgopal. (2005). The economic implications of corporate financial reporting. Journal of Accounting and Economics 40: 3-73.

Greene, W. (2010). Testing hypotheses about interaction terms in nonlinear models. Economics Letters 107 (2): 291-296.

Greenspan, A. (2002). Federal Reserve Board's semiannual monetary policy report to the congress - before the committee on banking, housing, and Urban Affairs, U.S. Senate July 16, 2002. Available at: https:// www.federalreserve.gov/boarddocs/hh/2002/july/testimony.htm.

Guay, W.R. (1999). The sensitivity of CEO wealth to equity risk: An analysis of the magnitude and determinants. Journal of Financial Economics 53 (1): 43-71.

Gunny, Katherine A. 2010. The relation between earnings management using real activities manipulation and future performance: Evidence from meeting earnings benchmarks*. Contemporary Accounting Research 27 (3): 855-888. https://doi.org/10.1111/j.1911-3846.2010.01029.x.

Hall, B.J., and K.J. Murphy. (2002). Stock options for undiversified executives. Journal of Accounting and Economics 33 (1): 3-42.

Haugen, R.A., and L.W. Senbet. (1981). Resolving the agency problems of external capital through options. The Journal of Finance 36 (3): 629-647.

Hayes, R.M., M. Lemmon, and M. Qiu. (2012). Stock options and managerial incentives for risk taking: Evidence from FAS 123R. Journal of Financial Economics 105 (1): 174-190.

Hayn, C. (1995). The information content of losses. Journal of Accounting and Economics 20 (2): 125-153.

Heron, R.A., and E. Lie. (2007). Does backdating explain the stock price pattern around executive stock option grants? Journal of Financial Economics 83 (2): 271-295.

Jacob, J., and B. Jorgensen. (2007). Earnings management and accounting income aggregation. Journal of Accounting and Economics 43 (2-3): 369-390.

Jayaraman, S., and T. Milbourn. (2015). CEO equity incentives and financial misreporting: The role of auditor expertise. The Accounting Review 90 (1): 321-350.

Jensen, M.C., and W.H. Meckling. (1976). Theory of the firm: Managerial behaviour, agency costs, and ownership structure. Journal of Financial Economics 3 (4): 305-360.

Jensen, M.C. (2005). Agency costs of overvalued equity. Financial Management 34 (1): 5-19.

Jiang, J.X., K.R. Petroni, and I.Y. Wang. (2010). CFOs and CEOs: Who have the most influence on earnings management? Journal of Financial Economics 96 (3): 513-526. 
Jochem, T., T. Ladika, and Z. Sautner. (2018). The retention effects of unvested equity: Evidence from accelerated option vesting. The Review of Financial Studies 31 (11): 4142-4186.

Johnson, S. A., H. E. Ryan Jr., and Y. S. Tian. (2003). Executive compensation and corporate fraud. Available at: $h$ ttp://ssrn.com/abstract=395960.

Karpoff, J., D.S. Lee, and G.S. Martin. (2008). The cost to firms of cooking the books. Journal of Financial and Quantitative Analysis 43 (3): 581-611.

Kasznik, R., and B. Lev. (1995). To warn or not to warn: Management disclosures in the face of an earnings surprise. The Accounting Review 70 (1): 113-134.

Kasznik, R., and M. McNichols. (2002). Does meeting earnings expectations matter? Evidence from analyst forecast revisions and share prices. Journal of Accounting Research 40 (3): 727-759.

Ke, B. (2001). Why do CEOs of publicly traded firms prefer reporting small increases in earnings and long strings of consecutive earnings increases? Available at: http://ssrn.com/abstract=250308.

Kile, C.O., and M.E. Phillips. (2009). Using industry classification codes to sample high-technology firms: Analysis and recommendations. Journal of Accounting, Auditing \& Finance 24 (1): 35-58.

Knowledge@Wharton. (2003). Stock options: The end of the affair? (July 30).

Ladika, T., and Z. Sautner. (2020). Managerial short-termism and investment: Evidence from accelerated option vesting. Review of Finance 24 (2): 305-344.

Lambert, R.A., D.F. Larcker, and R.E. Verrecchia. (1991). Portfolio considerations in valuing executive compensation. Journal of Accounting Research 29 (1): 129-149.

Levitt, A. (1998). The numbers game. Remarks delivered at the NYU Center for law and business, September 28, New York, NY.

Lie, E. (2005). On the timing of CEO stock option awards. Management Science 51 (5): 802-812.

Lopez, T., and L. Rees. (2002). The effect of beating and missing analysts' forecasts on the information content of unexpected earnings. Journal of Accounting, Auditing, and Finance 17 (2): 155-184.

Matsumoto, Dawn A. 2002. Management's incentives to avoid negative earnings surprises. The Accounting Review 77 (3): 483-514. http://www.jstor.org/stable/3068885. Accessed 7 Sept 2021.

McAnally, M.L., A. Srivastava, and C.D. Weaver. (2008). Executive stock options, missed earnings targets, and earnings management. The Accounting Review 83 (1): 185-216.

McConnell, P., J. Pegg, D. Mott, and C. Senyek. (2004). FASB does it: FAS 123(R) requires stock option expensing. Bear Stearns \& Co..

McConnell, P., J. Pegg, C. Senyek, D. Mott, and A. Calingsan. (2006). Primer on accounting for stock-based compensation: Stock options, restricted stock, and stock appreciation rights. Bear Stearns \& Co..

McVay, S., V. Nagar, and V.W. Tang. (2006). Trading incentives to meet the analyst forecast. Review of Accounting Studies. 11 (4): 575-598.

Murphy, K.J. (1999). Executive compensation. In Handbook of labor economics, ed. O. Ashenfleters and D. Card. North Holland.

Norton, E.C., H. Wang, and C. Ai. (2004). Computing interaction effects and standard errors in logit and probit models. The Stata Journal 4 (2): 154-167.

O’Connor, J.P., R.L. Priem, J.E. Coombs, and K.M. Gilley. (2006). Do CEO stock options prevent or promote fraudulent financial reporting? Academy of Management Journal 49 (3): 483-500.

Palmrose, Z.-V., V.J. Richardson, and S. Scholz. (2004). Determinants of market reactions to restatement announcements. Journal of Accounting and Economics 37 (1): 59-89.

Peng, L., and A. Röell. (2008). Executive pay and shareholder litigation. Review of Finance 12: 141-184.

Phillips, J., M. Pincus, and S. Rego. (2003). Earnings management: New evidence based on deferred tax expense. The Accounting Review 78 (2): 491-521.

Quinn, P. (2018). Shifting corporate culture: Executive stock ownership plan adoptions and incentives to meet or just beat analysts' expectations. Review of Accounting Studies 23 (2): 654-685.

Roberts, M. R., and T. M. Whited. (2013). Endogeneity in empirical corporate finance, in George M. Constantinides, Miltron Harris, and Rene M. Stulz., eds. Handbook of the economics of finance. Vol 2A: 493-572.

Roe, J., and K. Papadopoulos. (2019). 2019 U.S. executive compensation trends. Harvard law school forum on corporate governance, https://corpgov.law.harvard.edu/2019/04/16/2019-u-s-executive-compensationtrends/.

Ross, S.A. (2004). Compensation, incentives, and the duality of risk aversion and riskiness. The Journal of Finance 59 (1): 207-225.

Roychowdhury, S. (2006). Earnings management through real activities manipulation. Journal of Accounting and Economics 42 (2): 335-370.

Schipper, K. (1991). Analysts' forecasts. Accounting Horizons 5 (4): 105-121. 
Senyek, C., J. Pegg, D. Mott, and A. Calingasan. (2007). Consensus estimates exclude stock based compensation expense for 32\% of NASDAQ 100 companies. Bear Stearns Equity Research.

Skinner, D., and R. Sloan. (2002). Earnings surprises, growth expectations, and stock returns or don't let an earnings torpedo sink your portfolio. Review of Accounting Studies 7 (2): 289-312.

Smith, C.W., and R.M. Stulz. (1985). The determinants of firms' hedging policies. Journal of Financial and Quantitative Analysis 20 (4): 391-405.

Stein, J.C. (1989). Efficient capital markets, inefficient firms: A model of myopic corporate behaviour. The Quarterly Journal of Economics 104 (4): 655-669.

Trueman, B., F. Wong, and X. Zhang. (2001). Back to basics: Forecasting the revenues of internet firms. Review of Accounting Studies 6 (2-3): 305-329.

Wall Street Journal. (2002). In a key change, Coke to treat stock options as compensation. (July 15).

Yermack, D. (1997). Good timing: CEO stock option awards and company news announcements. The Journal of Finance 52 (2): 449-475. 